\title{
The labour market by education and occupation in 1992
}

Citation for published version (APA):

de Grip, A., Heijke, J. A. M., \& Dekker, R. (1989). The labour market by education and occupation in 1992. Researchcentrum voor Onderwijs en Arbeidsmarkt, Faculteit der Economische Wetenschappen. ROA Reports No. 8E https://doi.org/10.26481/umarep.198908E

Document status and date:

Published: 01/01/1989

DOI:

10.26481/umarep.198908E

Document Version:

Publisher's PDF, also known as Version of record

\section{Please check the document version of this publication:}

- A submitted manuscript is the version of the article upon submission and before peer-review. There can be important differences between the submitted version and the official published version of record.

People interested in the research are advised to contact the author for the final version of the publication, or visit the DOI to the publisher's website.

- The final author version and the galley proof are versions of the publication after peer review.

- The final published version features the final layout of the paper including the volume, issue and page numbers.

Link to publication

\footnotetext{
General rights rights.

- You may freely distribute the URL identifying the publication in the public portal. please follow below link for the End User Agreement:

www.umlib.nl/taverne-license

Take down policy

If you believe that this document breaches copyright please contact us at:

repository@maastrichtuniversity.nl

providing details and we will investigate your claim.
}

Copyright and moral rights for the publications made accessible in the public portal are retained by the authors and/or other copyright owners and it is a condition of accessing publications that users recognise and abide by the legal requirements associated with these

- Users may download and print one copy of any publication from the public portal for the purpose of private study or research.

- You may not further distribute the material or use it for any profit-making activity or commercial gain

If the publication is distributed under the terms of Article $25 \mathrm{fa}$ of the Dutch Copyright Act, indicated by the "Taverne" license above, 
THE LABOUR MARKET BY EDUCATION AND OCCUPATION IN 1992

ROA-R-1989/8E

A. de Grip

J.A.M. Heijke

R.J.P. Dekker

RESEARCH CENTRE FOR EDUCATION AND LABOUR MARKET

Faculty of Economic Sciences

Rijksuniversiteit Limburg

Maastricht, december 1989 
Grip, A. de

The labour market by education and occupation in 1992/ A. de Grip, J.A.M. Heijke, R.J.P. Dekker; [trans1. from the Dutch]. - Maastricht: Research Centre for Education and Labour market, Faculty of Economic Sciences, University of Limburg. - I11.(Report/Research Centre for Education and Labour Market; 1989/8E)

Vert. van: De arbeidsmarkt naar opleiding en beroep in 1992. - Maastricht: Researchcentrum voor Onderwijs en Arbeidsmarkt, 1989. - (Rapport/Researchcentrum voor Onderwijs en Arbeidsmarkt; 1989/8). - Met 1it. opg.

ISBN 90-5321-040-7

SISO 318.7 UDC $331.5+37(492)$ " $313 "$

Trefw. : arbeidsmarkt: Nederland; toekomst / onderwijs en arbeidmarkt; Nederland; toekomst. 
All rights reserved. No part of this publication may be reproduced or transmitted in any form or by any means, electronic, mechanical, photocopying recording or otherwise without prior permission of the director of the Research Centre for Labour Market and Education. In case of copying data must be referred to Research Centre for Labour Market and Education or ROA as data-source. 
2. FORECASTS OF EMPLOYMENT GROWTH

2.1. Introduction $\quad 5$

2.2. Employment growth by sector of industry 5

2.3. Employment growth by occupational class 6

2.4. Employment growth by educational group 9

3. FORECASTS OF REPLACEMENT DEMAND 13

3.1. Introduction 13

3.2. Replacement demand by occupational class 13

3.3. Replacement demand by educational group 18

4. FORECASTING THE POTENTIAL INFLOW OF SCHOOLLEAVERS 21

4.1. Introduction 21

4.2. Method 21

4.3. Results 24

5. JOB OPENINGS AND LABOUR MARKET PROSPECTS 26

5.1. Introduction 26

5.2. Job openings 26

5.3. Labour market perspectives by educational group 27

6. RISK INDICATORS $\quad 32$

6.1. Introduction 32

6.2. Sensitivity to the business cycle 32

6.3. Dispersion indicator 34

7. CONCLUSION

$\begin{array}{lr}\text { LITERATURE } & 41\end{array}$

ANNEX 1: Overall review of cyclical sensitivity by occupational class (fluctuation index FI)

ANNEX 2: Overal1 review of sectoral dispersion by occupational class (Gini-Hirschmann coefficient GH) 
ANNEX 3: Overall review of the occupational dispersion by education (GiniHirschmann coefficient $\mathrm{GH}$ )

ANNEX 4: Overall review of the sectoral dispersion by education (Gini-Hirschmann coefficient $\mathrm{GH}$ ) 


\section{ACKNOWLEDGEMENT}

The investigation reported is part of a research assignment given to the Research Centre for Education and Labour Market (ROA) by the Ministry of Education and Sciences, which stretches over several years. The assignment is to develop an information system with respect to the relation between education and labour market, which is to serve as a guidance for study and career choices. The investigation has been supported by a complementary assignment within the I-See! project, of which the organization rests with the National Service Centre (LDC).

The purpose of the I-See! project is to accommodate information about occupations, types of education and the labour market in one automated system that is interactively accessible for consultation on study and career choices. The I-See! product, a CD-ROM, is to be put on the market in the early months of 1990; it addresses in the first instance those acting as intercessors in the choice of educational groups or careers (school deans, study and career advisors, and labour exchanges). The ROA has produced the data for the so-called labour market module of I-See! (De Grip, Heijke, Dekker, Beekman and Peeters, 1989).

The present investigation was supervised by Professor J.A.M. Heijke, director of the ROA. Day-to-day management was entrusted to Dr A. de Grip. Drs R.J.P. Dekker, Drs Th.B.J. Beekman and Drs H.M.M. Peeters contributed to the research. M.H. Wieling assisted in the processing and analysis of the data material. 


\section{INTRODUCTION}

The primary objective of the ROA education/labour market information system is to generate information useful for study and career choices. In principle, this ROA information system could also be helpful towards the planning of educational capacity, job creation, policy concerned with economic structure and technology, and manpower policy of the public and private sectors.

The present volume reports on the progress made with the information system. One improvement on the previous report (De Grip, Heijke, Dekker and Groot, 1987) is that for the first time information has been generated across the full width of the educational system. Besides, the forecasting models have been extended. In the coming years the information system will be developed further. The forecasting models will be improved and statistical basic data updated and completed. Moreover, labour market indicators so far not included in the information system but nevertheless relevant for the choice of educational groups and careers (and for other target groups) will be identified, and the possibility of regionalizing the labour market information probed. The plan is to issue new forecasts every other year.

The present report focuses on the two most important components of the information system as it exists now: the medium-term forecasts of labour market prospects and the so-called 'risk indicators' with respect to educational groups and occupational classes $^{1}$. Moreover it provides quantitative support to the qualitative descriptions of the labour market prospects and risk indicators displayed on the I-See! screen. The figures have purposely been kept out of the screen to keep users from attaching too much value to the exact results of forecasts as such. That would not be justified, in view of the margins of uncertainty inherent to such forecasts. This report mentions the figures for the sole purpose of justifying the labour market forecasts and risk indicators we have produced.

In the 1980s, an increasing attention for the influence of labour market factors on the choice of education could be observed. For one thing, government campaigns were mounted to stimulate students to choose an exact or technical programme or a vocational education; for another, job-creation schemes and retraining projects were much extended in the 1980s. Such labour market instruments can be regarded as a form

1. I-See! presents in addition a large number of historical data. So, for the application of historical data in an education/labour-market information system, please see the I-See! product. 
of curative policy (De Grip 1987), intended to correct discrepancies between supply and demand on the labour market after they have arisen. However, for a proper qualitative match between supply and demand on the labour market, a preventive policy is essential, with much attention to information about the labour market prospects of the individual educational groups and occupations. The question arises what information is needed to prevent or get rid of short demand and excess supply on the labour market. Indeed, if a line of study is chosen solely with a view to the current situation on the labour market rather than realistic medium-term prospects, so-called cobwebs may well develop.

On the other hand, policy makers are now aware that the labour market is not quite so controllable as was assumed in the 1960s, when so-called 'manpower planning' was very popular. Especially the underlying assumption of a direct relation between a given educational group and a given occupation, and the absolute significance attached to labour market forecasts, produced practical problems. The present tendency is towards models that are econometrically more consistent, and to take into account that, for instance, the educational structure of an occupation and a business sector are apt to change through time. Moreover we must admit, that the more general forecasts of the Central Planning Bureau (CPB) are of little help towards vocational and occupational counselling because the aggregation level of the educational categories distinguished by the $\mathrm{CPB}$ is too high and data on occupations are not available.

The ROA information system on education and labour market distinguishes types of education and occupations on a much lower level of aggregation. However, further disaggregation increases the probability of forecasts not corresponding with the realization. On a high level of aggregation, some shifts in the educational and occupational structures remain within the classes distinguished, and forecasting errors have a greater chance of cancelling each other out. To overcome the drawback of wider error margins, the forecasts of the labour market turned out by the computerized information system for study and career choices I-See! - for which ROA, as said before, has supplied the labour market data - are not presented in 'exact' quantified terms but only as indicative qualitative indications. To our mind such a qualitative description of the labour market prospects of educational groups and occupational classes suffices for the object envisaged: to consider the labour market prospects when choosing an education or an occupation.

The medium-term forecasts for the occupations consist of two components:

- the expected expansion demand (employment growth); 
- the expected replacement demand.

In that way, a picture is obtained of the expected so-called job openings in the various occupational classes.

In the forecasts of the labour market prospects for the various educational groups, the number of 'job openings' forecast (extension and replacement demand) is set off against the expected potential inflow of schoolleavers/graduates into the labour market. In that way, a qualitative description of the labour market prospects of each educational group is derived. No account is taken of the volume of present unemployment, one reason being that its actual influence on the labour market prospects of recently graduated schoolleavers is obscure.

The labour market forecasts are completed with labour market indicators giving information about the current labour market situation and the risks involved in a given choice of study or career. These so-called risk indicators refer to the sensitivity of employment to the business cycle and the potential mobility to other occupations or other business sectors, if necessary. The advantage of this approach is that the labour market prospects can be considered in relation to other labour market aspects of occupations and educational groups.

The forecasts refer to the period from 1985 to 1992. 1985 is the base year because unfortunately it is the most recent year for which detailed historical data of the labour market are known. The forecasts envisage the medium term, long enough to take the situation on the labour market at the time of graduation into account, but not so long as to make the forecasts unacceptably uncertain. At the time of computation, CPB forecasts by business sector for the year 1994 were not yet available, so that for the time being we have to be content with a forecast for 1992 .

The ROA information system distinguishes 23 sectors of activity, 79 occupational classes and 53 educational groups. The sectors are based on the classification which the Central Planning Bureau uses for its Central Economic Plan. The occupational classes correspond to the 2-digit level of the classification operated by the Central Bureau of Statistics. The entire educational system has been divided, on the basis of the Standard Education Classification (3-digit code), into 53 marketrelevant educational groups. Together, these classifications permit a differentiated survey of the expected developments on the labour market.

The present division into occupational classes does not make for an optimum match between education and labour market (nurses and physicians, for instance, are put in 
the same occupational class). ROA researchers have already been working on an alternative division into more homogeneous occupational classes in relation to the education required (De Grip, Groot and Heijke, 1987), derived from the more detailed breakdown into 320 occupational groups. However, because the future availability of data in such detail is uncertain, for the time being a more conservative attitude towards the occupational classification to be used remains preferable.

The remainder of this report is organized as follows. Chapter 2 discusses the employment forecasts by sector of activity (section 2.2), occupational class (section 2.3) and educational group (section 2.4). Chapter 3 goes into replacement demand by occupational class and educational group. Chapter 4 goes on to forecast the expected potential inflow of schoolleavers into the labour market. Chapter 5 sets the inflow of schoolleavers off against total demand for labour by educational group. Chapter 6 deals with risk indicators. To complete the report, chapter 7 surveys the present state of the ROA education-labour market information system and its possible further developments. 


\section{FORECASTS OF EMPLOYMENT GROWTH}

\subsection{Introduction}

The employment forecasts for the 1985-92 period build on to the employment estimates in man years by sector of activity drawn up by the Central Planning Bureau. First, employment in man years is converted into employed persons by the persons/workyears $(\mathrm{P} / \mathrm{W})$ ratio. Next, the employed persons by sector are distributed among the 79 occupational classes distinguished. Finally, employment forecasts are drawn up for 53 educational groups, account being taken of expected shifts in the sectoral and occupational structure. A distinction is made between level and branch of education. By forecasting first the number of persons employed in a sector and next distributing them among occupations and educational groups, the consistency between forecasts is ensured. The following sections go into the details of the forecasts and underlying models.

\subsection{Employment growth by sector of industry}

The sectoral forecasts follow the medium-term estimates of the Central Planning Bureau, which project labour volume ${ }^{2}$ (in man years) up to 1990 in a sectoral breakdown that can be connected to the 23 sectors distinguished in the ROA information system. Next, the projected $\mathrm{P} / \mathrm{W}$ ratios of the sectors are applied to the projected sectoral man-year figures to accomplish the conversion into employed persons. Unfortunately, forecasts of $\mathrm{P} / \mathrm{W}$ ratios are available only on a higher level of aggregation. Nor are CPB forecasts of the labour volume or the $\mathrm{P} / \mathrm{W}$ ratios available beyond 1990. Therefore, the ROA itself had to take care of the projection of both employment and $\mathrm{P} / \mathrm{W}$ ratio for 1991 and 1992. It has done so on the basis of the average growth of the variables involved in the 1985-1990 period.

Table 1 presents the forecast of employment in persons employed. The expectation is that total employment will be 10 per cent higher in 1992 than it was in 1985. Comparison with the previous forecast (De Grip, Heijke, Dekker and Groot 1987, p. 11) shows no change in average expected employment growth, although differences can be observed for separate sectors. These differences are largely due to CPB's recent adjustments of labour volume forecasts by industry.

2. Central Economic P1an 1989, Annex D (diskette). 


\begin{tabular}{|c|c|c|c|}
\hline & $\begin{array}{c}\text { Persons } \\
\text { employed } \\
1985 \\
\end{array}$ & $\begin{array}{c}\text { Persons } \\
\text { employed } \\
1992 \\
\end{array}$ & $\begin{array}{l}\text { \% mutation } \\
1985-92\end{array}$ \\
\hline 1. Agriculture, fishing, forestry & 268.1 & 266.4 & -0.6 \\
\hline 2. Manufacture of foodstuffs, beverages, tobacco products & 165.9 & 172.2 & 3.8 \\
\hline 3. Manufacture of textiles, wearing apparel, leather and footwear & 55.6 & 58.2 & 4.7 \\
\hline 4. Manufacture of wood and building materials & 72.9 & 79.0 & 8.3 \\
\hline 5. Manufacture of paper and printing and publishing industries & 114.5 & 132.4 & 15.6 \\
\hline 6. Chemical industry and manufacture of rubber and plastic products & 115.5 & 133.7 & 15.8 \\
\hline 7. Basic metal industries & 33.3 & 34.6 & 3.8 \\
\hline \multicolumn{4}{|l|}{ 8. Manufacture of metal products, mechanical and instrument } \\
\hline 9. Electrical engineering & 100.7 & 106.7 & 5.4 \\
\hline 10. Manufacture of transport equipment & 71.0 & 73.0 & 2.8 \\
\hline 11. Petroleum industry & 9.5 & 9.9 & 3.8 \\
\hline 12. Mining and quarrying & 11.4 & 12.3 & 7.9 \\
\hline 13. Electricity, gas and water & 44.1 & 45.7 & 3.6 \\
\hline 14. Construction & 385.7 & 411.0 & 6.6 \\
\hline 15. Ownership of dwellings & 30.8 & 36.6 & 18.8 \\
\hline 16. Trade & 720.0 & 861.6 & 19.7 \\
\hline 17. Sea and air transport & 51.0 & 59.6 & 16.9 \\
\hline 18. Transport, storage and communication & 271.7 & 311.6 & 14.7 \\
\hline 19. Banking and insurances & 185.9 & 207.3 & 11.5 \\
\hline 20. Other private services & 560.9 & 666.1 & 18.8 \\
\hline 21. Medical and veterinary services & 374.7 & 422.9 & 12.9 \\
\hline 22. Other public services & 426.6 & 473.7 & 11.0 \\
\hline 23. Public administration and education ${ }^{*}$ & 780.5 & 809.0 & 3.7 \\
\hline Total & 5143.4 & 5664.4 & 10.1 \\
\hline * Including professional soldiers (average 42.3) & & & \\
\hline
\end{tabular}

Source: CPB/ROA

\subsection{Employment growth by occupational class}

From the sectoral forecasts, forecasts of employment growth by occupational class have been derived. The Labour-Force Censuses provide, for alternate years of the 1975-1985 period, data of the distribution of persons employed in occupational classes among business sectors. In Dekker, De Grip and Heijke (1988) the first steps were taken towards an economic explanation of the occupational structure by sector. Besides technological advance (investment, automation), cyclical factors (utilization rate) and structural (trend) effects have been included in the model. The point of departure is the estimated share of occupation 0 in the employment of sector s. To connect employed persons (the variable to be explained) with the regressors reflecting the effect on the labour volume, account is taken of the development of the average working hours by occupation and by sector. In view of the limited period for which data are available, the data of each occupational class have been pooled over the sectors to obtain more data (and hence more degrees of 
freedom) for each estimation. The sectors have been divided into two main groups: agriculture and industry versus services. The parameters of the exogenous variables have been assumed equal for all sectors of a main group. Next, the following equation has been estimated for each occupation:

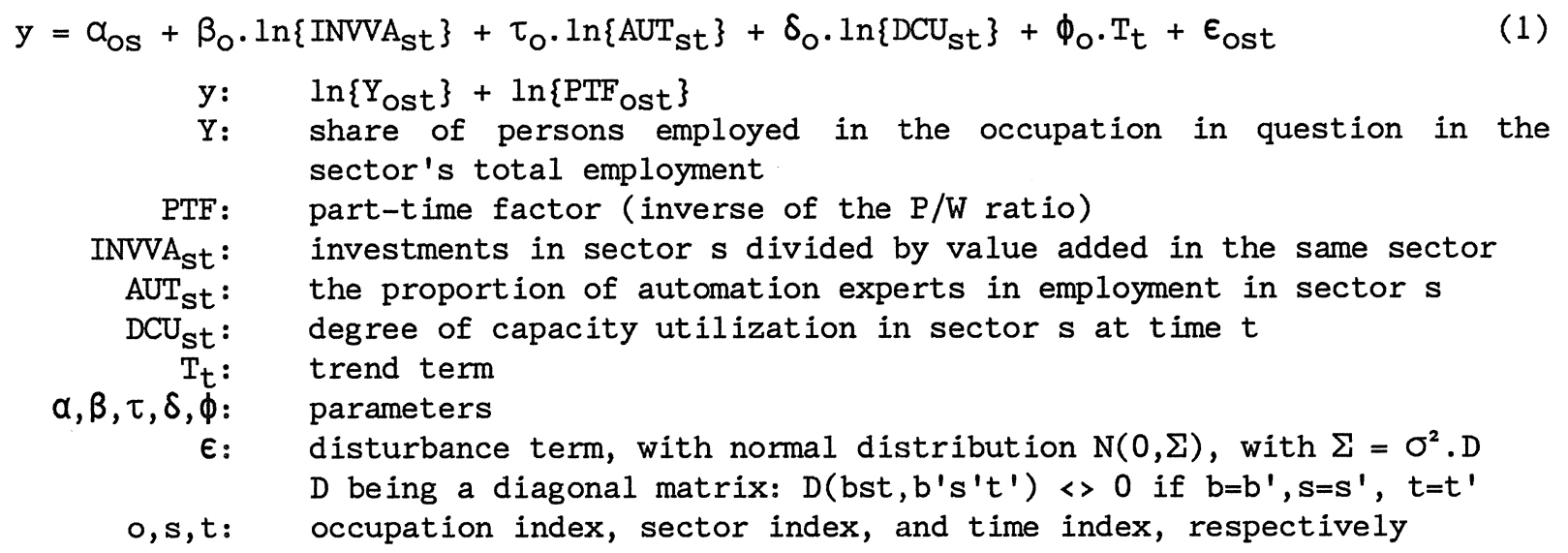

Should only the sectoral constant prove significant in the estimation of the model, then the occupation would have a constant share in the sector. The investments related to the value added and the share of automation staff in a sector are indicative of technological advance (see Dekker, De Grip and Heijke 1988). The utilization degree has been approximated by relating the value added in the current year to the five-year progressive mean of value added. The trend has been included exponentially, which makes the parameter easier to interpret, but carries the risk of the trend 'exploding'. For that reason, in the model selection first a test is carried out to verify whether the trend is significant. Is that test rejected, then a further test is carried out to establish whether the explanatory variables (apart from the trend) are significant in respect of the model with sector constants alone. To compensate for the fact that the estimated employment shares do not account for the absolute numbers of persons employed in an occupation in a sector, the equations were estimated by means of weighted least squares, the shares being weighted with the number of persons employed in that occupation in that sector. The weighting ensures that shares representing a large number of employed persons count heavier for the establishment of the parameters. A fortuitous advantage is that the weighting corrects as well for heteroscedasticity due to the fact that measurement errors can be relatively great for small numbers.

For the estimation results we refer to the working paper by Dekker, De Grip and Heijke (1988) mentioned before. Here we will just consider the results of the computation of the model for 1992 . 
Tables $2 a$ and $2 b$ represent, respectively, the fastest growing and fastest declining occupations. On inspection, we find many traditional industrial occupations among the fast decliners as well as some small occupations. Some caution is advisable, for one thing because the data are derived from a sample, and for another because measurement errors tend to reflect heavier in the number of employed persons in small than in large occupations. Moreover, with the former category, even a minor change in absolute numbers may be enormous in terms of percentages.

Besides medical occupations, service occupations are among the fast risers, the occupations with relatively low educational requirements being strongly represented in absolute figures. Indeed, shop assistants and cleaners account for one sixth of the total employment growth.

Table 2a. Fast growing occupational classes, 1985-1992

\begin{tabular}{|c|c|c|c|c|}
\hline code & Occuptional class & $\begin{array}{c}\text { number of } \\
\text { working persons } \\
1985 \\
\end{array}$ & $\begin{array}{c}\text { number of } \\
\text { working persons } \\
1992 \\
\end{array}$ & $\begin{array}{l}\% \\
\text { growth }\end{array}$ \\
\hline 08 & Statisticians, mathematicians and related technicians & 50,700 & 95,200 & 88 \\
\hline \multirow[t]{2}{*}{55} & Building caretakers, charworkers, cleaners and & & & \\
\hline & related workers & 139,500 & 192,200 & 38 \\
\hline 50 & Managers (catering and lodging services) & 13,200 & 16,600 & 26 \\
\hline \multirow[t]{2}{*}{32} & Stenographers, typists and card- and tape-punching & & & \\
\hline & machine operators & 148,100 & 185,700 & 25 \\
\hline 48 & Salesmen, shop assistants and related workers & 251,000 & 313,400 & 25 \\
\hline 85 & Electrical fitters and related electric and electronics workers & 111,100 & 138,200 & 24 \\
\hline 34 & Computing machine operators & 11,500 & 14,100 & 23 \\
\hline \multirow[t]{2}{*}{47} & Insurance, real estate, securities and business services, & & & \\
\hline & salesmen and auctioneers & 34,300 & 42,200 & 23 \\
\hline 30 & Clerical supervisors & 17,600 & 21,500 & 22 \\
\hline 06 & Medical, dental, veterinary and related workers & 267,500 & 324,800 & 21 \\
\hline
\end{tabular}

Source: ROA

Table 2b. Fast declining occupational classes 1985-1992

\begin{tabular}{llccc}
\hline code & occupational class & $\begin{array}{c}\text { number of } \\
\text { working persons } \\
1985\end{array}$ & $\begin{array}{c}\text { number of } \\
\text { working persons } \\
1992\end{array}$ & $\begin{array}{c}\% \\
\text { decline }\end{array}$ \\
\hline & & & & -42 \\
96 & Stationary engine and related equipment operators & 6,000 & 3,500 & -28 \\
73 & Wood preparation workers and paper makers & 7,200 & 5,200 & -21 \\
83 & Blacksmiths, toolmakers and machine tool operators & 40,500 & 32,200 & -12 \\
86 & Broadcasting station and sound equipment operators & & & -9 \\
& and cinema projectionists & 2,100 & 1,800 & -8 \\
71 & Miners, quarrymen, well drillers and related workers & 1,700 & 1,500 & -8 \\
52 & Housekeeping and related service supervisors & 10,400 & 9,600 & -6 \\
84 & Machinery fitters, machine assemblers and precision- & & & -6 \\
& instrument makers (except electrical) & 155,500 & 143,600 & -6 \\
38 & Telephone and telegraph operators & 18,100 & 17,000 & 94,400 \\
70 & Production supervisors and general foremen & 100,600 & 12,500 & \\
94 & Production and related worker N.E.C. & 13,200 & & \\
\end{tabular}




\subsection{Employment growth by educational group}

From the projected employment by industry and the shares of occupational classes in sectoral employment, the forecast of employment by educational group can be derived. Once we have estimated the employment shares of an educational group in all sectoroccupation combinations, we can compute employment by educational group, taking into account shifts in the sectoral and occupational patterns. The educational model explains in addition the shifts in the educational shares within occupational classes.

Our data material stretches only to four Labour-Census years (between 1979 and 1985), because in 1978 the CBS revised the classification of the educational system. Once more the data have been pooled over sector and occupation.

The educational model has been described in more detail in Beekman, Dekker, De Grip and Heijke (1989). At this place the regressors and the estimated equations will be considered briefly, more attention being devoted to the estimates of employment growth by educational group in the period between 1985 and 1992. The educational model falls apart into two submodels. The first submodel distinguishes five levels of education, corresponding with the first digit of the SOI/ISCED-code (elementary education, the lower levels of secondary general and vocational education, the higher levels of secondary general and vocational education, higher vocational education, and scientific education). The second submodel distinguishes, on each leve1, several disciplines (for instance technical, agricultural). The combination of levels and disciplines sums up to a total of 53 educational groups (see annex $3)$.

Technological progress is included as a possible explanation of shifts in the pattern of educational levels of the occupations in a sector. Where new techniques are being used, functions may be upgraded; in that case the introduction of new technology leads to higher educational requirements. In other occupations or sectors, on the contrary, mechanization and automation may entail the downgrading of functions. The final effect is hard to predict. As with the occupational model of section 2.3, a sector's capital intensity and degree of automation are taken as indicators of its technological advance.

Shifts in the educational level of occupations can also be initiated by supply factors, however. In a recession period, lower-skilled workers may be crowded out from their 'occupational territory' by higher qualified ones. The phenomenon is 
known as 'downward displacement', or 'bumping-down processes'. It works strictly one-way: only persons with a higher level of education crowding out those with a lower level. In the neo-classical view, displacement is described in terms of the relative scarcity of an educational level, expressed in the relative wages. Since no adequate wage data are available, we have to be content with an approximation of that relative scarcity. Displacement in the neo-classical sense can work both downward and upward. For explanatory variable we have chosen the number of persons with a given educational level as a fraction of the total potential labour force (PLF).

In equation 2, the share of educational level 1 in an occupation 0 and sector $s$ is determined by a constant term, the share of that educational level in the potential labour force (the displacement variable), investment by unit of value added in sector $s$, and the share of automation staff in that sector's employment (technology variables). We use dumny variables for the occupations to take account of differences among occupations not expressed in the exogenous variables mentioned.

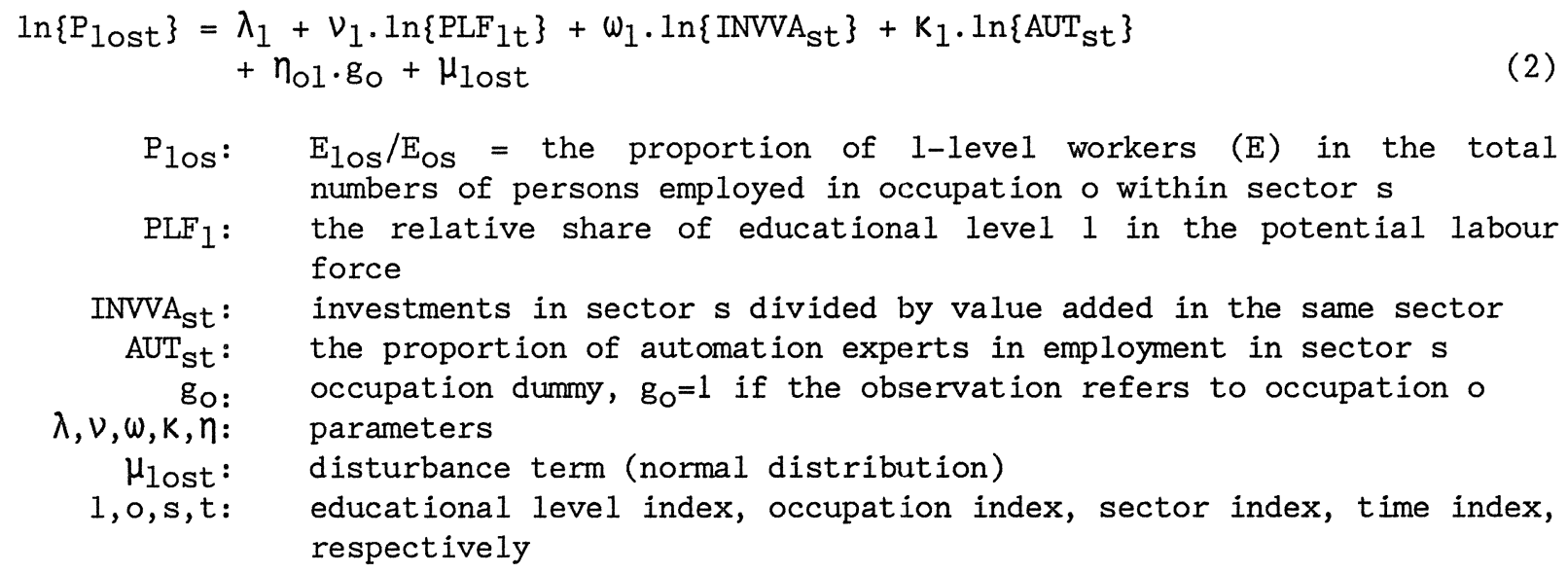

$\mathrm{P}_{10 \mathrm{~S}}: \quad \mathrm{E}_{1 \mathrm{OS}} / \mathrm{E}_{\mathrm{OS}}=$ the proportion of 1-leve1 workers (E) in the total numbers of persons employed in occupation 0 within sector $s$

$\mathrm{PLF}_{1}$ : the relative share of educational level 1 in the potential labour INVVA $_{\text {St }}$ investments in sector $s$ divided by value added in the same sector

$\mathrm{AUT}_{\mathrm{st}}$ : the proportion of automation experts in employment in sector $\mathrm{s}$

$\mathrm{g}_{\mathrm{o}}$ occupation dumny, $\mathrm{g}_{\mathrm{O}}=1$ if the observation refers to occupation $\mathrm{O}$ $\lambda, \nu, \omega, k, \eta: \quad$ parameters

$\mu_{\text {lost }}$ : disturbance term (normal distribution)

1,o,s, t: educational level index, occupation index, sector index, time index, respectively

A simple specification, determining the employment shares of a branch of study in a given occupation in a given sector by a constant term and a trend term, suffices to establish that discipline's share in a level of education. No explanatory variables have been included because we are not sure of the processes which determine the shares held by various disciplines in the employment of a given level of education within an occupation. In theory, we could assume similar processes as were incorporated in the first submodel, and specify corresponding exogenous variables, such as - to the analogy of the PLF-variable - the share of the various disciplines in the potential labour force. In practice that is impossible, however, for lack of the required data by discipline. The constant term has been broken down into a general, an occupation-specific, and a sector-specific constant. The specification 
reads as follows:

$\ln \left\{R_{d o s} 1 t\right\}=\theta_{d}+\pi_{d o} \cdot g_{o}+\xi_{d s} \cdot d_{s}+\tau_{d o} \cdot T_{t}+\psi_{d o s} 1 t$

$\mathrm{R}_{\text {dos } 1 \mathrm{t}}: \quad \mathrm{E}_{\mathrm{dos} 1 \mathrm{t}} / \mathrm{E}_{\mathrm{osk}}=$ share of people of discipline $\mathrm{d}$ employed in occupation 0 , sector $s$, and educational level 1 at $t$ ime $t$

go: occupation dummy, $g_{0}=1$ if the observation refers to occupation 0

$d_{\mathrm{s}}$ : sector dumm, $\mathrm{d}_{\mathrm{S}}=1$ if the observation refers to sector $\mathrm{s}$

$\mathrm{T}_{\mathrm{t}}$ : trend term

$\theta, \pi, \xi, \tau: \quad$ parameters

$\Psi_{\text {dos1t }}$ disturbance term normal distributed

$\mathrm{d}, \mathrm{o}, \mathrm{s}, 1, \mathrm{t}$ : discipline index, occupation index, sector index, educational

level index, time index, respectively

By analogy of the first submodel, we estimate this equation for each discipline. As with the occupational model a weighted linear regression is carried out (see section 2.3).

The modelling in two stages implies that the development of each discipline's employment share is broken down into independent aspects of level and discipline. The first step determines the employment share by level of education. Sometimes, a certain level already implies certain disciplines, because the sets of disciplines vary from one level of education to another. So, the disciplinary shifts in the educational structure explained by the second submodel are supplementary to the changes in disciplinary structure already implicit in the model of educational levels.

Table 3 displays the fastest winners and losers among the educational groups emerging from the computation of the model for 1992. Especially among the growers the percentages are high. Keep in mind that the fastest growers are often relatively small-scale courses. The share of lower clerical courses is observed to be strongly on the wane, whereas comparable courses on the secondary level are increasing fast.

The figures of table 3 are also influenced by the shift of the occupational structure towards service occupations (table 2). Indeed, table 3 presents the shifts in educational structure that occurred after incorporation of the shifts in the sectoral and occupational structures. 
Table 3a. Persons employed by educational group, 1985-1992; fastest growers

\begin{tabular}{|c|c|c|c|c|}
\hline code & educational group & $\begin{array}{c}\text { number of } \\
\text { working persons } \\
1985 \\
\end{array}$ & $\begin{array}{c}\text { number of } \\
\text { working persons } \\
1992 \\
\end{array}$ & $\begin{array}{l}\% \\
\text { growth }\end{array}$ \\
\hline 662 & Econometrics, actuary and management (B.Sc.) & 3,600 & 11,100 & 212 \\
\hline 351 & Junior medical and paramedical education & 2,900 & 8,400 & 191 \\
\hline 652 & Pharmacy & 1,700 & 4,300 & 159 \\
\hline 562 & $\begin{array}{l}\text { Courses for ergonomists and management science at } \\
\text { the higher technical school, etc. }\end{array}$ & 2,900 & 6,200 & 118 \\
\hline 554 & Dietetics college, etc. & 1,900 & 3,200 & 66 \\
\hline 583 & Hotel college & 3,100 & 5,100 & 62 \\
\hline 431 & Senior school for laboratory science & 6,400 & 9,800 & 53 \\
\hline 452 & Secondary school for medical laboratory science, higher level & 20,600 & 31,000 & 50 \\
\hline 483 & Secondary hotel and catering school, hairdresser's school & 32,500 & 48,200 & 48 \\
\hline 461 & Senior retail school and intermediate business education & 529,800 & 773,800 & 46 \\
\hline
\end{tabular}

\section{Source: ROA}

Table 3b. Persons employed by educational group, 1985-1992; fastest decliners

\begin{tabular}{llccc}
\hline code & educational group & $\begin{array}{c}\text { number of } \\
\text { working persons } \\
1985\end{array}$ & $\begin{array}{c}\text { number of } \\
\text { working persons } \\
1992\end{array}$ & $\begin{array}{c}\% \\
\text { decline }\end{array}$ \\
\hline & & & & -27 \\
341 & Junior transport, communication and traffic education & 32,500 & 23,600 & -21 \\
586 & Art academy, academy of dramatic art & 27,400 & 21,500 & -21 \\
486 & Fashion drawing, etc. & 1,900 & 1,500 & -17 \\
361 & Lower business education, secondary school for tradesman & & & -11 \\
& (lower level), practical training for clerks and salesmen & & & -8 \\
& at the school for domestic science and technique & 142,100 & $-711,400$ & -6 \\
506 & Training college for primary and pre-primary school teachers, & & -4 \\
& secondary-school teacher training, new style & 227,500 & 202,100 & -4 \\
406 & Training for driving instructor, sports coach & 35,000 & 32,100 & 36,600 \\
671 & Socio-cultural sciences & 39,200 & 4,500 & 64,500 \\
511 & Training for interpreters and translators & 4,800 & 7,500 & \\
571 & College of social studies, library studies & 67,100 & & \\
616 & Theology & 7,900 & &
\end{tabular}




\section{FORECASTS OF REPLACEMENT DEMAND}

\subsection{Introduction}

How many jobs will be available for newcomers on the labour market depends, besides the increase in the total number of jobs, also on the demand for replacement of present workers who are going to resign in the near future. Replacement demand ensues from on the one hand, the final withdrawal from the labour force of workers reaching the age of normal or early pensioning, and on the other hand the retirement for a number of years of married women to take care of and educate their children.

For the purpose of the employment forecasts, estimates have been made of replacement demand by occupational class (section 3.2). Apart from the outflow from the labour force, the net flows to and from other occupational classes (the occupational mobility of the employed) play a part. The computations produce the theoretical replacement demand. Actually, new manpower will be recruited only if there is no decline in employment, that is to say, if extension demand is not negative. So, for a realistic estimate of future job openings in an occupation for newcomers on the labour market, the estimates for replacement demand and expansion demand in that occupation have to be added up. Section 3.3, finally, converts the replacement demand for occupational classes into the replacement demand for individual educational groups.

\subsection{Replacement demand by occupational class}

To establish replacement demand by occupational class, in principle an explanatory model could be constructed. However, in view of the data constraints and the need for 1992 projections of exogenous variables, such a model would take a lot of time and trouble to develop. For that reason, we have preferred a model relying on the age pattern of those practising an occupation (the age cohorts of occupational classes).

The available data of employment by occupational class, age group and sex for 1979 and 1985, and the labour force by age group and sex for 1979, 1985 and 1992 (CPB, Op de Beke, 1987) permit us to use the cohort method to forecast replacement demand by occupational class. The nature of the data prevents us from establishing the portion of replacement demand that is taken up by newcomers in the same age group. Therefore, what can be measured is the net outflow of a cohort from the occupational class. 
We establish replacement demand from the calculated net outflow. On the assumption of an equal spread of year groups within the individual age cohorts, the net outflow or inflow of workers of a certain age from the labour force can be established by comparing the number of workers of age $c$ in 1985 with the number of workers who are forecast to be $c+7$ years of age in 1992. On that basis the annual net outflow from the labour force can be calculated for the various age cohorts. The method will be described in more concrete terms below.

Let $O C_{c t}$ be the number of persons from cohort $c$ employed in an occupational class at time $t$; then the net outflow from cohort $c$ in that occupational class between year $t$ and year $t-j$ is:

$\mathrm{FOC}_{\mathrm{ct}, \mathrm{t}-\mathrm{j}}=O \mathrm{C}_{\mathrm{c}, \mathrm{t}} / O \mathrm{CC}_{\mathrm{c}, \mathrm{t}-\mathrm{j}}$

$O C_{c, t-j}$ refers to the same cohort at time $t-j$.

Similarly, the net outflow from the total number of persons employed, $F W P_{c t, t-j}$, and from the total labour force, $F_{c L}, t_{-j}$, can be determined. All outflow ratios are determined for men and women separately. For either sex we thus get the following data:

$\mathrm{FOC}_{\mathrm{C} 8579}, \mathrm{FWP}_{\mathrm{C} 8579}, \mathrm{FLF}_{\mathrm{C} 8579}$ and $\mathrm{FLF}_{\mathrm{C} 9285}$

Because the 1979-85 and 1985-92 periods differ in length, we convert the net outflow in a period into annual growth rates:

$\mathrm{gFOC}_{\mathrm{C} 8579}, \mathrm{gFWP}_{\mathrm{C} 8579}, \mathrm{gFLF}_{\mathrm{C} 8579}$ and $\mathrm{gFLF}_{\mathrm{C} 9285}$.

To establish replacement demand, information is needed about the annual net outflow from the cohorts in an occupational class in the 1985-92 period for all c: FOC $_{\mathrm{C} 8592}$. This expected net outflow can be computed as follows:

$\mathrm{gFOC}_{\mathrm{C} 9285}=\mathrm{gFOC}_{\mathrm{c} 8579}-\left(\mathrm{gFWP}_{\mathrm{C} 8579}-\mathrm{gFLF}_{\mathrm{c} 9285}\right)$

So, the annual net outflow by occupational class equals the net outflow from it in the previous period, with two 'corrections'. The first concerns the cyclical component in the past period: $\mathrm{gFLF}_{\mathrm{c} 8579}-\mathrm{gFWP}_{\mathrm{c} 8579}$. The correction for the difference between the net outflow from the labour force and that from the employed population prevents distortion of the pattern by a cyclical component of the 
development (the outflow of employed people to the stock of unemployed). The second correction factor, $\mathrm{gFLF}_{\mathrm{C} 9285}-\mathrm{gFLF}_{\mathrm{C} 8579}$, represents the change in the net outflow from the total labour force in the future period. The assumption is that the differences between the periods $1985-92$ and 1979-85 in the overall pattern of the outflow from the labour force are reflected in the various occupational classes.

To calculate replacement demand we only need data on the outflow by occupational class. Therefore we will consider only the cohorts which net outflows are positive (in particular the older age groups). Sumation of the outflow over the cohorts and the two sexes produces the calculated total replacement demand for the occupational class involved.

Tables $4 \mathrm{a}$ and $4 \mathrm{~b}$ reproduce the ten occupational classes with the highest and lowest relative replacement demands. The average replacement demand in the 1985-92 period amounts to some 18 per cent of the number of employed in 1985. For various occupational classes, particularly in manufacturing industry, the replacement demand found is distinctly above-average. The fact must be kept in mind that, as pointed out before, the demand established is the theoretical replacement demand. The occupational classes of table 4a (with high replacement demand) are often classes in which employment is stagnating, so that actual replacement occurs only as far as employment in that occupational class is not contracting.

Among the occupational classes with relatively low replacement demand we find several occupations with a relatively young population, some with many graduate employees. In these occupational classes, any 'job openings' on the labour market must largely be hoped for from the growth of employment.

Table 4a. Occupational classes with the highest relative replacement demand, 1985-1992

\begin{tabular}{llccc}
\hline code & occupational class & $\begin{array}{c}\text { number of } \\
\text { working persons } \\
1985\end{array}$ & $\begin{array}{c}\text { replacement } \\
\text { demand }\end{array}$ & $\begin{array}{c}\text { in \% of working } \\
\text { persons } \\
1985\end{array}$ \\
\hline & & & & 46 \\
75 & Spinners, weavers, knitters, dyers and related workers & 11,400 & 5,200 & 40 \\
99 & Labourers n.e.c. & 45,900 & 18,300 & 37 \\
81 & Cabinetmakers, woodworkers and related workers & 16,600 & 6,100 & 35 \\
71 & Miners, quarrymen, well drillers and related workers & 1,700 & 600 & 35 \\
73 & Wood preparation workers and paper makers & 7,200 & 2,500 & 35 \\
94 & Production and related workers n.e.c. & 13,200 & 4,600 & 34 \\
95 & Bricklayers, carpenters and other construction workers & 169,000 & 57,300 & 33 \\
83 & Blacksmiths, toolmakers and machine tool operators & 40,500 & 13,200 & 32 \\
87 & Plumbers, welders, sheet metal and structural metal & & & 34,500 \\
\end{tabular}


Table 4b. Occupational classes with the lowest relative replacement demand, 1985-1992

\begin{tabular}{|c|c|c|c|c|}
\hline code & occupational class & $\begin{array}{c}\text { number of } \\
\text { working persons } \\
1985\end{array}$ & $\begin{array}{l}\text { replacement } \\
\text { demand }\end{array}$ & $\begin{array}{c}\text { in \% of working } \\
\text { persons } \\
1985\end{array}$ \\
\hline \multirow[t]{2}{*}{86} & Broadcasting station and sound equipment operators & & & \\
\hline & and cinema projectionists & 2,100 & 0 & 0 \\
\hline 08 & Statisticians, mathematicians, and related technicians & 50,700 & 1,500 & 3 \\
\hline 15 & Authors, journalists and related workers & 20,000 & 1,200 & 6 \\
\hline 78 & Tobacco preparers and tobacco-product makers & 2,100 & 100 & 6 \\
\hline 12 & Jurists & 18,400 & 1,400 & 8 \\
\hline 40 & Managers (wholesale) & 30,200 & 2,200 & 8 \\
\hline 05 & Life scientists and related technicians & 29,300 & 2,600 & 9 \\
\hline 17 & Composers and performing artists & 17,600 & 1,500 & 9 \\
\hline 19 & Professional, technical and related workers n.e.c. & 110,200 & 9,600 & 9 \\
\hline 41 & Managers (retail trade) & 16,600 & 1,500 & 10 \\
\hline
\end{tabular}

Source: ROA

Besides replacement demand by occupational class, the demand for schoolleavers on the labour market has also been forecast. A portion of total demand (expansion and replacement demand) is indeed taken up by entrants from other occupational classesso-called occupational mobility- and re-entrants (newcomers who are not schoolleavers). Given the extent of occupational mobility and re-entrance, total demand for schoolleavers in an occupational class can be defined as follows:

$\mathrm{DS}_{\mathrm{O}}=\Delta \mathrm{E}_{\mathrm{O}}+\sum_{\mathrm{C}=1}^{\mathrm{C}}\left(\mathrm{O}_{\mathrm{OC}}-\mathrm{R}_{\mathrm{OC}}\right)$,

with: $\mathrm{DS}_{\mathrm{O}}=$ demand for schoolleavers in occupation $\circ$

$\Delta \mathrm{E}_{\mathrm{O}}=$ employment growth in occupation $\mathrm{O}$

$\mathrm{O}_{\mathrm{OC}}=$ outflow from occupation $\mathrm{o}$, cohort $\mathrm{c}$

$\mathrm{R}_{\mathrm{OC}}=$ re-entry in occupation $\mathrm{o}$, cohort $\mathrm{c}$

$\mathrm{C}=$ numbers of cohorts

While for the establishment of replacement demand by occupational class only those cohorts were considered for which the net outflow was positive $\left(O_{O C}-R_{O C}>0\right)$, to assess the demand for schoolleavers the cohorts whose net outflow is negative owing to the inflow from other occupational classes or the inflow of re-entrants into the labour force must also be taken into account. The assumption is that in the below-30 age group only schoolleavers flow into an occupation. In practice that will by no means be the rule. Hence, for our purpose the term 'schoolleavers' should actually be understood to refer to the inflow opportunities of workers below the age of 30 into an occupational class. 
Tables 5a and 5b present the occupational classes in which between 1985 and 1992 the greatest absolute and relative demand for schoolleavers is expected. In absolute terms, many 'schoolleavers' may enter as clerical staff, shop assistants, construction workers. secretaries, bank clerks, or (medical or) nursing staff. In relative terms, the demand for new young employees is highest in the occupational class 'directors and managers of hotels and catering companies', which is rather surprising since numerous other executive functions are not instantly accessible to young employees (see table 6). Next in line come various industrial occupations.

Table 6 presents the occupational classes into which no direct inflow of schoolleavers is expected for the 1985-92 period. Apart from some craft and manufacturing occupations, most of these classes contain supervising and executive functions. The explanation may be that essentially these functions are not open to beginners, but can only be attained after passing through other occupations.

Table 5a. Occupational classes with the highest relative demand for schoolleavers, 1985-1992

code occupational class in \% of working persons in 1985

$\begin{array}{lll}50 & \text { Managers (catering and lodging services) } & 55 \\ 08 & \text { Statisticians, mathematicians and related technicians } & 54 \\ 75 & \text { Spinners, weavers, knitters, dyers and related workers } & 44 \\ 48 & \text { Salesmen, shop assistants and related workers } & 43 \\ 32 & \text { Stenographers, typists and card- and tape-punching machine operators } & 41 \\ 87 & \text { Plumbers, welders, sheet metal and structural metal preparers and erectors } & 40 \\ 34 & \text { Computing machine operators } & 38 \\ 85 & \text { Electrical fitters and related electric and electronics workers } \\ 63 & \text { Forestry workers } & 38 \\ 95 & \text { Bricklayers, carpenters and other construction workers } & 37\end{array}$

Source: ROA

Table 5b. Occupational classes with the highest absolute demand for schoolleavers, 1985-1992

\begin{tabular}{llc}
\hline code & occupational class & number \\
\hline & & 122,000 \\
49 & Clerical and related workers n.e.c. & 107,900 \\
95 & Salesmen, shop assistants and related workers & 60,800 \\
32 & Bricklayers, carpenters and other construction workers & 60,700 \\
33 & Stenographers, typists and card- and tape-punching machine operators & 59,000 \\
06 & Bookkeepers, cashiers and related workers & 58,900 \\
98 & Medical, dental and veterinary and related workers & 43,000 \\
87 & Transport equipment operators & 42,200 \\
85 & Plumbers, welders, sheet metal and structural metal preparers and erectors & 41,800 \\
02 & Electrical fitters and related electric and electronics workers & 41,200 \\
\end{tabular}


Table 6. Occupational classes for which no direct inflow of schoolleavers is expected in the 1985-1992 period

\begin{tabular}{ll}
\hline code & occupational class \\
\hline 05 & Life scientists and related technicians \\
09 & Economists \\
12 & Jurists \\
14 & Workers in religion \\
15 & Authors, journalists and related workers \\
17 & Composers and performing artists \\
19 & Professional, technical and related workers n.e.c. \\
20 & Legislative officials and government administrators \\
21 & Managing and higher executive functions exclusive of public administration \\
30 & Clerical supervisors \\
35 & Transport and communications supervisors \\
37 & Mail distribution clerks \\
38 & Telephone and telegraph operators \\
40 & Managers (wholesale) \\
41 & Managers (retail trade) \\
47 & Insurance, real estate, securities and business services, salesmen and auctioneers \\
52 & Housekeeping and related service supervisors \\
60 & Farm managers and supervisors \\
70 & Production supervisors and general foremen \\
78 & Tobacco preparers and tobacco-product makers \\
80 & Shoemakers and leather goods makers \\
86 & Broadcasting station and sound equipment operators and cinema projectionists \\
90 & Rubber and plastics product makers \\
91 & Paper and paperboard product makers \\
96 & Stationary engine and related equipment operators \\
& \\
\hline
\end{tabular}

Source: ROA

\subsection{Replacement demand by educational group}

For the replacement demand, a similar model or algorithm as has been developed for the occupational classes would be advisable. That would imply not only acquiring the necessary data, but also separating replacement demand from extension demand. Replacement demand for educational groups is a notion that is difficult to handle, for occupational mobility does not give instant information about replacement demand by educational group, and extension demand by educational group already comprises a portion of replacement. The fact is that extension demand by educational group comprises the shifts among educational group within an occupational class, and thus implicitly the replacement of an employee with a certain educational background with a newcomer with a different background. Remains to be explained the replacement demand in an occupational class that can be fulfilled by newcomers with the same educational background as the outflowing employees.

At an earlier stage, efforts were made to establish replacement demand simply by counting how may over-55s were employed in each occupation in 1985, and assuming that this entire group leaves the labour market between 1985 and 1992 (De Grip, 
Heijke, Dekker and Groot, 1987). Next, the outcomes were converted, according to the 1985 structure of occupations and educational groups, into replacement demand by educational group. Failing data about education by age group within an occupational class, that approach required the additional assumption that the distribution of educational groups by occupational class does not depend on the age structure of an occupation. Thus, this approach does not take account of the withdrawal of working people at younger ages (in particular women). To circumvent that problem, another method has been used in the present study.

This time replacement demand by occupational class as determined in the previous section, has been distributed among educational groups according to the educational structure of occupations. Aware of the fact that this method is not optimal either, we are now looking for more adequate data (education by age and sex, participation degree, etc.), thus to add to the possibilities of constructing a model of replacement demand by educational group. From tables $7 a$ and $7 b$, presenting some results of the present approach - distribution of replacement demand by occupation among educational groups -, we observe that the extremely high and low percentages found for the occupations, have been levelled down. Most probably that is due to the distribution of replacement demand by occupation among educational groups. Especially with the larger educational groups we find among the fastest risers many lower and secondary educational groups, against a higher level among the slow risers.

Table 7a. Educational groups with the highest relative replacement demand 1985-1992

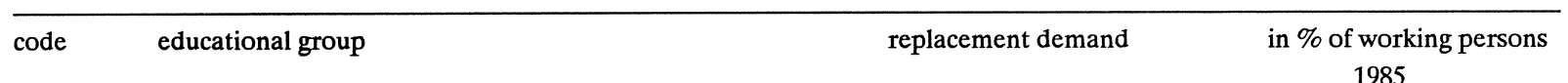

\begin{tabular}{llrl}
\hline & & & \\
& & & \\
541 & Senior education in transportation, communication & 9,500 & 23 \\
& and traffic science & 4,700 & 21 \\
481 & Transport, communication and traffic college & 6,700 & 20 \\
421 & Secondary hotel and catering school, hairdresser's school & 18,800 & 20 \\
453 & Senior agricultural education & 800 & 19 \\
321 & Training for medical clerks, etc. & 20,100 & 19 \\
361 & Junior agricultural education & & 19 \\
& Lower business education, secondary school for & 27,100 & 19 \\
381 & tradesman (lower level), practical training for clerks & & 18 \\
& and salesman at the school for domestic science and technique & 43,300 & \\
& School for domestic science and techinique exclusive of & 600 & \\
\hline
\end{tabular}


Table 7b. Educational groups with the lowest relative replacement demand 1985-1992

\begin{tabular}{llrl}
\hline code & educational group & replacement demand & in \% of working persons \\
& & & 1985 \\
\hline 652 & Pharmacy & 200 & 10 \\
551 & Nursing college, physiotherapy college & 5,000 & 11 \\
552 & College for medical laboratory science & 2,000 & 11 \\
562 & Courses for ergonomists and management science at the & & 11 \\
& higher technical school, etc. & 300 & 11 \\
571 & College of social studies, library studies & 7,500 & 11 \\
606 & Teacher training (highest level) & 1,600 & 11 \\
611 & Language and literature & 1,900 & 11 \\
636 & Technical sciences & 4,200 & 11 \\
651 & Medical sciences & 3,800 & 11 \\
671 & Socio-cultural sciences & 4,300 & \\
\end{tabular}

Source: ROA 


\section{FORECASTING THE POTENTIAL INFLOW OF SCHOOLLEAVERS}

\subsection{Introduction}

Employment forecasts alone are not sufficient to describe the prospects for schoolleavers on the labour market. Indeed, their chances of a suitable job also depend on the intensity of their competition for the limited number of jobs available. A more realistic insight into their prospects on the labour market is given, therefore, by setting off the projected demand for newcomers on the labour market (the job openings) against the projected potential inflow from the educational system. Chapter 5 will give the details of that confrontation; the present chapter describes how to forecast the potential inflow of schoolleavers into the labour market. The present description improves on the previous report on the prospects for schoolleavers on the labour market (De Grip, Heijke, Dekker and Groot, 1987) in that the projection of the potential inflow of schoolleavers into the labour market now extends to all educational groups.

\subsection{Method}

Efforts have been made to forecast, for each educational group, how many students leaving school in the period between 1985-86 and 1991-92 with a certificate will flow into the labour market. Since a considerable portion of the forecasting period is already past, we have been able to use realized figures as far as they have come available.

To draw up the forecasts, the following sources have been tapped:

- Time series from the 1988 education forecast of the CPB, also called SKILL '88.

- WORSA ' 88 and RHOBOS 188 of the Student Estimates Task Group of the Ministry of Education and Sciences.

- Various CBS statistics (among others, the 1985 education matrix, and statistics of recognized correspondence courses).

- Other external information (data about students of non-regular courses).

Figure 1 gives a schematic representation of the method followed.

The Central Planning Bureau (CPB) publishes annual forecasts of the number of students in full-time initial education, the number of schoolleavers, and the educational level of the population up to the 2000-2001 study year. These so-called 'SKILL forecasts' are differentiated by sex and age. The SKILL data refer to a much 
higher level of aggregation than the educational groups we have distinguished, so distribution keys are needed to break down the SKILL forecasts to suit our purpose.

WORSA (estimates of numbers of students in scientific education) and RHOBOS (estimates of numbers of students in higher vocational education) give estimates of the number of persons leaving the educational system, respectively for scientific and higher vocational education. Both estimates are based on the SKILL forecast of the Central Planning Bureau, SKILL educational groups being broken down to a lower level of aggregation. However, the WORSA and RHOBOS breakdowns do not exactly match the educational groups we have distinguished, so that for our purpose we have had to combine some and further break down others.

No equivalents of the RHOBOS and WORSA studies are available for lower and secondary vocational and secondary general education, so we have built on directly to the SKILL forecasts and developed our own distribution keys to achieve the breakdown matching the educational groups distinguished in our information system. Next, the estimates of students leaving school with a diploma need to be converted into outflow percentages from the educational system. That is necessary because some schoolleavers may enrol in full-time education (at a higher level) again instead of forthwith offering themselves on the labour market.

Besides those leaving school with a diploma, SKILL distinguishes students who end their studies without a diploma. With the help of the education matrix they can be re-assigned to any preliminary course they had crowned with a diploma.

Data about non-regular education (apprenticeships, recognized correspondence courses, training in medical care), have to be taken from available additional statistics, or obtained directly from the training courses concerned. Of that category's inflow into the labour market, too, a forecast has been drawn up. However, enrolment in non-regular courses changes the qualification profile of 'schoolleavers'. For that reason, the number of the students who have successfully completed such courses have to be proportionally detracted from their preliminary regular educational groups. Another correction is needed to prevent students enrolling in several non-regular courses or a regular course of the same type being counted twice. In that way a forecast can be drawn up of the outflow from both regular and non-regular educational groups into the labour market ${ }^{3}$.

3. In particular for non-regular education the data position is still poor; efforts are being made towards a more systematic processing of data for this segment of the educational system. 


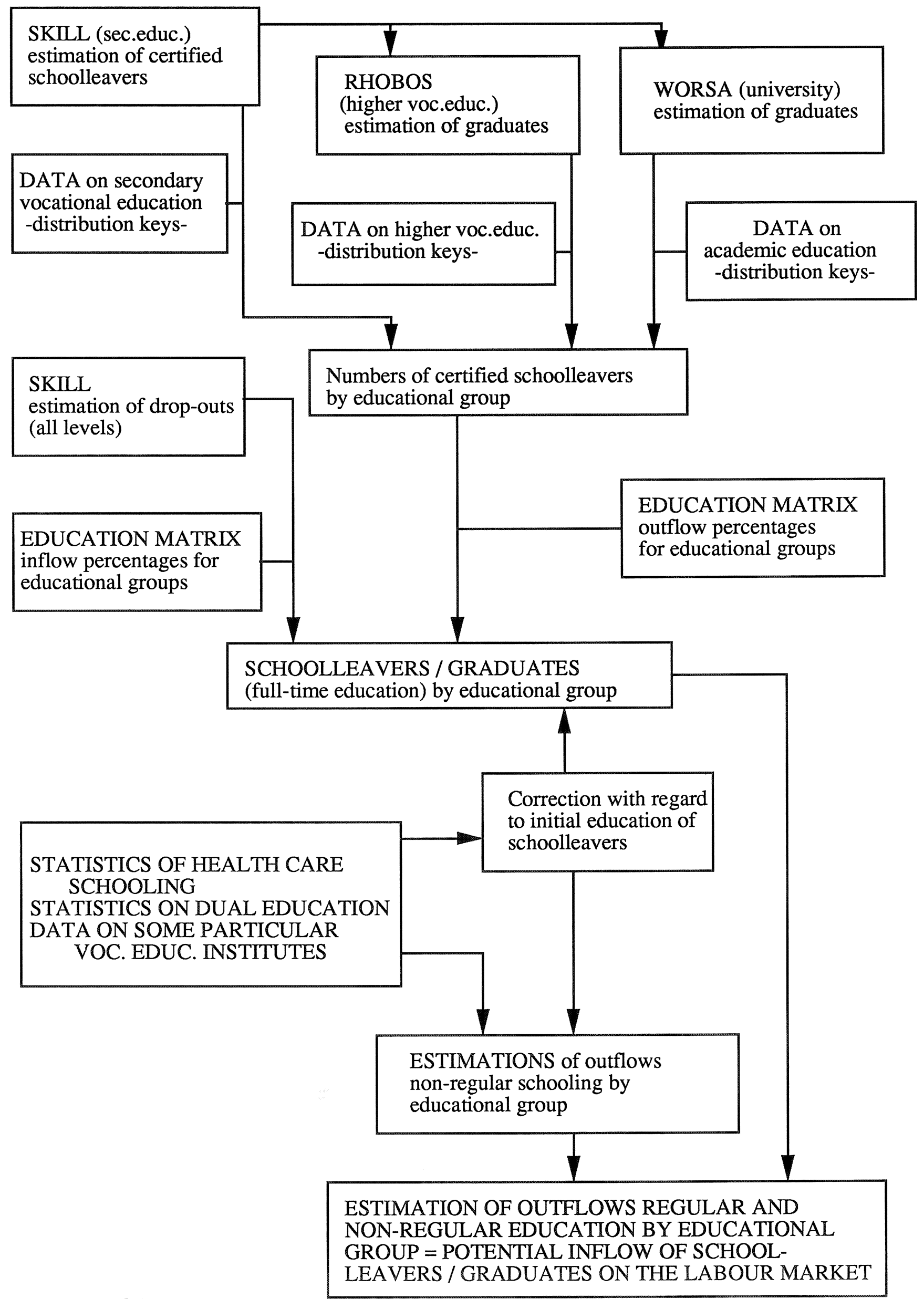




\subsection{Results}

Table 8 represents the potential inflow from the educational groups we have distinguished into the labour market, cumulated over the period from 1985 to 1992 and expressed in percentages of the total number of people with that particular educational background employed in 1985.

A high inflow does not automatically imply poor prospects on the labour market. It may even be an advantage when there is also much demand for people with a certain education. Nevertheless the potential inflow is presented separately on the consideration that the results of the confrontation between potential inflow and job openings as such cannot explain whether a poor labour market perspective is due to surplus inflow of, or a poor demand for manpower with that particular training, or to both factors.

Especially higher vocational and scientific educational groups display high inflow percentages. On the secondary vocational level, fashion drawing (code 486) also has an impressive potential inflow, but we wonder whether the persons involved will actually enter the labour market. The educational groups under code 391, business security and surveillance training, also display high inflow figures, but mark that, with an average number of employed of 3,600 in the 1979-85 period, the course counts a relatively small number of students. In such circumstances, even a moderate absolute rise represents a high percentage. 
Table 8. Potential inflow into the labour market by educational group, 1985-1992, in percentages of the number of persons employed in 1985

code

educational group

Secondary education, lower level

301

321

331

341

351

361

381

391

401

406

421

431

436

441

451

452

453

454

461

466

471

481

483

486

General secondary education

Junior agricultural education

Junior technical education

Secondary education, higher level

Senior agricultural education

Senior school for laboratory science

Senior technical training

medical and other services

Training for medical clerks, etc.

Training for ward orderlies, etc.

services or the INTAS

Fashion drawing, etc.

Higher vocational education

Training for interpreters and translators

Training for pastoral work, etc.

Agricultural college

Laboratory college

Technical college

Nursing college, physiotherapy college

College for medical laboratory science

Dietetics college, etc.

technical school, etc.

College of social studies, library studies

Hotel college

Art academy, academy of dramatic art

Scientific education

inflow \%

Junior transport, communication and traffic education

Junior medical and paramedical education

Lower business education, secondary school for tradesmen (lower level),

practical training for clerks and salesmen at the school for domestic sciences and technique 45

School for domestic science and technique exclusive of training for clerks and salesmen $\quad 19$

Business security and surveillance training

General secondary education, intermediate and higher levels $\quad 101$

Training for driving instructor, sports coach

Senior education in transportation, communication and traffic science

Training of nurses and medical receptionists at the secondary school for

Secondary school for medical laboratory science, higher level

Senior retail school and intermediate business education

Intermediate business education, department of management studies

Social work and welfare work (secondary school for medical and other services)

External care, services as taught at the secondary school for medical and other

Secondary hotel and catering school, hairdresser's school

Training college for primary and pre-primary school teachers,

secondary-school teacher training, new style

Transport, communication and traffic college

Business science college, exclusive of administrative and fiscal studies

Courses for ergonomists and management science at the higher

Business science college, legal and administrative studies

Teacher training (highest level)

Language and literature $\quad 121$

$\begin{array}{lr}\text { Theology } & 13\end{array}$

$\begin{array}{lr}\text { Agricultural and domestic sciences } & 103\end{array}$

$\begin{array}{lr}\text { Mathematics and physics } & 56\end{array}$

$\begin{array}{lr}\text { Technical sciences } & 48\end{array}$

Medical sciences $r$

$\begin{array}{lr}\text { Pharmacy } & 125\end{array}$

$\begin{array}{lr}\text { Economics and business administration (B.A.) } & 88\end{array}$

Econometrics, actuary and management (B.Sc.) 105

\begin{tabular}{lr} 
Law & 95 \\
\hline
\end{tabular}

$\begin{array}{lr}\text { Fine arts } & 224 \\ \end{array}$ 


\section{JOB OPENINGS AND LABOUR MARKET PROSPECTS}

\subsection{Introduction}

As pointed out in chapter 4, a confrontation of expected potential inflow into the labour market with the total number of job openings in the forecast period is feasible for educational groups, but not for occupations. The reason is that education, being a personal characteristic, offers no unequivocal lead towards the supply to be expected for a given occupation. Only on the level of educational qualifications are supply and demand confronted on the labour market. As a matter of fact, here supply and demand (of qualifications) have to be matched.

The difference between job openings and expected potential supply must not be interpreted as a measure of unemployment. For one thing, we are not considering expected actual supply on the labour market, but potential supply. For another, no account is taken of unemployment in the base year of the forecasting period (for the very reason, among others, of preventing the interpretation of the forecasts in terms of expected unemployment). Moreover, the degree to which schoolleavers and (in particular long-term) unemployed are actually vying for the same jobs, is hard to establish. And finally, although we have tried to incorporate crowding-out processes in the employment model for educational groups, in a very easy labour market such effects may well prove much stronger than assumed. So, if there is a surplus of high-skilled manpower, schoolleavers may more than is assumed in our forecast end up in jobs (far) below their level of education. From the point of view of study and career choice their labour market prospects may be called poor, even when they secure a job.

Section 5.2 gives a review of job openings by occupational class and educational group. Section 5.3 derives for each educational group a labour market perspective from the relation between potential inflow into the labour market and job openings by educational group.

\subsection{Job openings}

By the term 'job openings' we understand, as said before, the total of replacement and extension demand. The Bureau of Labor Statistics of the American Ministry of Employment uses this term to indicate that jobs may come available from an increase in employment as well as from demand for replacement. Because by definition the number of new jobs cannot be negative, the number of job openings by occupation must 
be larger than, or equal to, 0 . That is why in table 9, which makes a distinction between extension and replacement demand, the number of job openings is set at 0 in the few cases where extension and replacement demand add up to a negative total.

The figures of table 9 show that replacement demand accounts for a far from negligible portion of all expected job openings. For some executive occupations (cfr. codes 20, 30,50, 60, and 70), extension demand is low but replacement demand high. That means that these occupations, while offering stable overall job opportunities, yet represent a dynamic segment of the labour market because of a relatively large outflow of elderly employees. Likewise, a relatively large number of job openings may be expected for occupations in the sectors clerical and commercial functions (whose first code digits are 3 and 4, respectively).

\subsection{Labour market perspectives by educational group}

Table 10 reproduces the job openings for the various educational groups, broken down, to the analogy of table 9, into extension and replacement demand. Table 10 again confirms the important share of extension demand in the total number of job openings. Replacement demand by educational group shows on the whole less extreme figures than replacement demand by occupation. That may be due, as remarked before, to the levelling influence of weighting with the occupational patterns.

Table 11 represents the ratio between potential inflow into the labour market and job openings. The greater the inflow in relation to demand, the higher the ratio. A high ratio thus indicates an easy labour market for that particular educational group; a low ratio indicates that the sub-market in question is expected to be tight in the near future. For some educational groups we find extremely high or negative outcomes. Negative outcomes are the result of a 'negative' demand; they occur because with educational groups, we have not set negative job openings at 0 .

The ratio of potential inflow and job openings is translated into a 'qualitative definition of the expected labour market prospect'. To our mind, such a qualitative definition suffices for the purpose of study and career choice, and moreover prevents too much significance being attached to the exact forecasting results. The classification of the expected labour market prospects is based on a division into five categories: 
ratio $\leq 0$ or $>8$

$4<$ ratio $\leq 8$

$2<$ ratio $\leq 4$

$1<$ ratio $\leq 2$

$0<$ ratio $\leq 1$ very poor labour market prospects

poor labour market prospects

moderate labour market prospects

reasonable labour market prospects

good labour market prospects

For educational groups with a negative ratio, demand appears to be declining while the supply is not over-generous. An exception is educational group 486, Fashion drawing etc. which does display a very large supply. A very poor labour market situation is also expected for 361, Lower business education, secondary school for tradesman (lower level), practical training for clerks and salesmen at the school for domestic science and technique; 506, Training college for primary and preprimary school teachers, secondary-school teacher training, new style; 511, Training for interpreters and translaters; 571, College of social studies, library studies; and 671, Socio-cultural sciences for which demand, while positive, is very small.

For the educational groups 391, Business security and surveillance training; 401, General secondary education, intermediate and higher levels; 611, Language and literature; and 686, Fine arts, on the other hand, the labour market situation is poor owing to a relatively large inflow. The following educational groups have good labour market prospects: 301, General secondary education; 331, Junior technical education; 351, junior medical and paramedical education; 381, School for domestic science and technique exclusive of training for clerks and salesmen; 421, Senior agricultural education; 441, Senior education in transportation, communication and traffic science; 452, Secondary school for medical laboratory science, higher level; 461, Senior retail school and intermediate business education; 466, Intermediate business education, department of management studies; 483, Secondary hotel and catering school, hairdresser's school; 516, Training for pastoral work, etc.; 541, Transport, communication and traffic college; 561, 566 Business science college; 562, Courses for ergonomists and management science at the higher technical school, etc.; 583, Hotel college; 652, Pharmacy; and 662, Econometrics and business administration (B.A.). 
Table 9. Extension demand, replacement demand and job openings by occupational class, 1985-1992, in percentages of the number of persons employed in 1985

\begin{tabular}{lcccc}
\hline code & occupational class & extension demand & replacement demand & job \\
& & $\%$ & $\%$ & openings $\%$ \\
\hline
\end{tabular}

$01 \quad$ Physical scientists and related technicians

04 Aircraft and ships' officers
05 Life scientists and related technicians
Medical, dental, veterinary and related workers

Statisticians, mathematicians and related technicians

Economists

Accountants

Jurists

Teachers

Workers in religion

Authors, journalists and related workers

Sculptors, painters, photographers and related creative artists

Composers and performing artists

Athletes, sportsmen and related workers

Professional, technical and related workers n.e.c.

Legislative officials and government administrators

Managing and higher executive functions exclusive

of public administration

Clerical supervisors

Government executive officials

Stenographers, typists and card- and tape-punching

machine operators

Bookkeepers, cashiers and related workers

Computing machine operators

Transport and communications supervisors

Transport conductors

Mail distribution clerks

Telephone and telegraph operators

Clerical and related workers ne.c.

Managers (wholesale)

Managers (retail trade)

Working proprietors (wholesale)

Shopkeepers, street vendors

Sales supervisors and buyers

Technical salesmen, commercial travellers and

manufacturer's agents

Insurance, real estate, securities and business services,

salesmen and auctioneers

Salesmen, shop assistants and related workers

Managers (catering and lodging services)

Working proprietors (catering and lodging services)

Housekeeping and related service supervisors

Cooks, waiters, bartenders and related workers

Maids and related housekeeping workers n.e.c.

Building caretakers, charworkers, cleaners and related

workers

Launderers, dry-cleaners and pressers

Hairdressers, barbers, beauticians related workers

Protective service workers

Service workers n.e.c.

Farm managers and supervisors

Farmers

Agricultural and animal husbandry workers

Forestry workers

Fishermen, hunters and related workers

Production supervisors and general foremen

Miners, quarrymen, well drillers and related workers

Metal processors

Wood preparation workers and paper makers

Chemical processors and related workers

Spinners, weavers, knitters, dyers and related workers

Food and beverage processors

Tobacco preparers and tobacco-product makers

Tailors, dressmakers, sewers, upholsterers and

related workers

Shoemakers and leather goods makers

Cabinetmakers, woodworkers and related workers

Blacksmiths, toolmakers and machine tool operators

$12 \quad 16 \quad 28$

28

14

Machinery fitters, machine assemblers and precision-instrument

makers (except electrical)

Electrical fitters and related electric and electronics workers

Broadcasting station and sound equipment operators and

cinema projectionists

Plumbers, welders, sheet metal and structural metal

preparers and erectors

Jewellery and precious metal workers

Glass formers, potters and related workers

Rubber and plastics product makers

Paper and paperboard product makers

Printers and related workers

Painters

Production and related workers. n.e.c.

Bricklayers, carpenters and other construction workers

Stationary engine and related equipment operators

Material handling and related equipment operators, dockers

and freight handlers

Transport equipment operators

Labourers n.e.c. 
Table 10. Extension demand, replacement demand and job openings by educational group, 1985-1992, in percentages of the number of persons employed in 1985

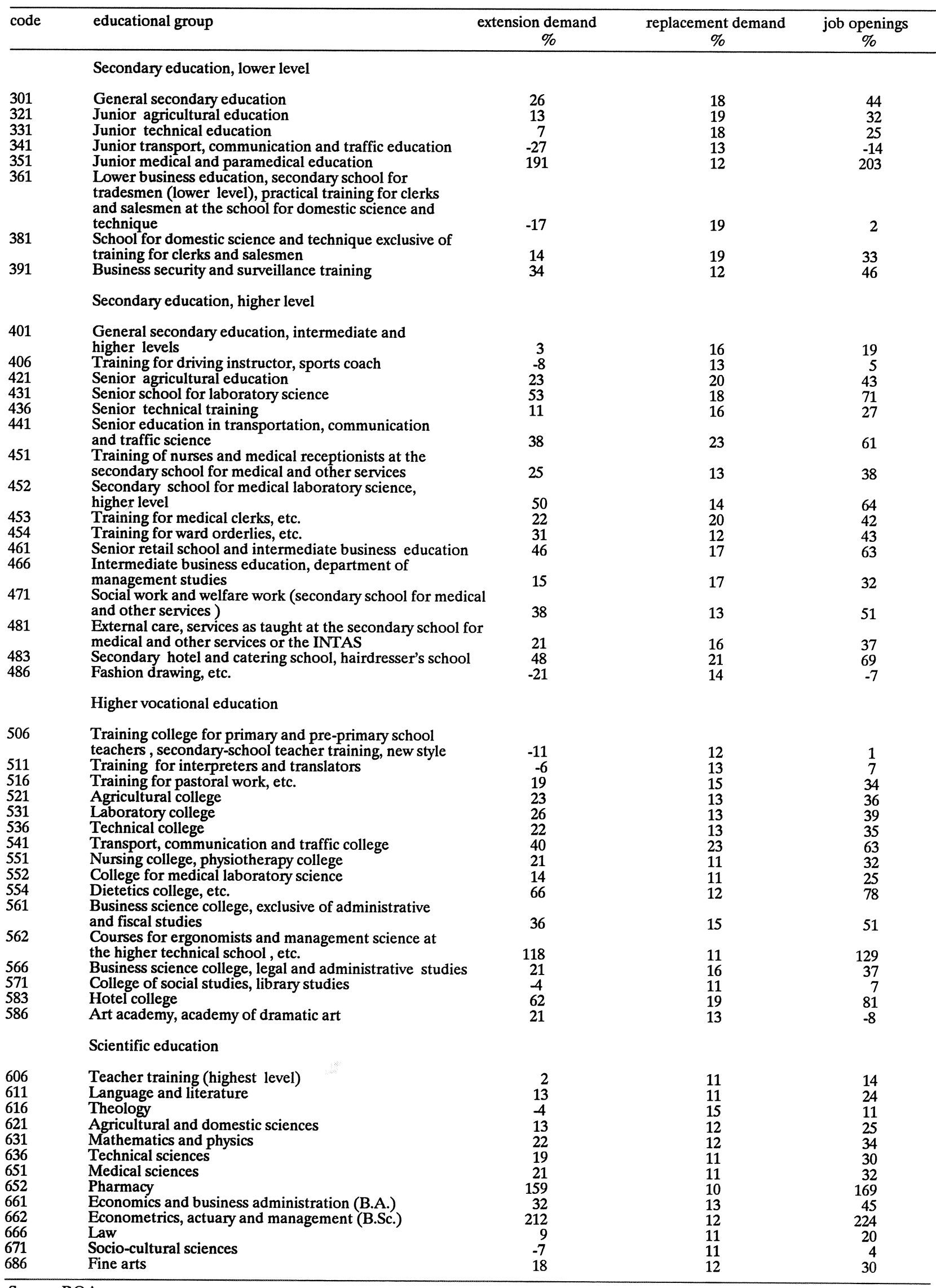


Table 10. Extension demand, replacement demand and job openings by educational group, 1985-1992, in percentages of the number of persons employed in 1985

\begin{tabular}{llccc}
\hline code & educational group & extension demand & replacement demand & job openings \\
& & $\%$ & $\%$
\end{tabular}

Secondary education, lower level

301

321

331

341

361

$381 \quad$ School for domestic science and technique exclusive of

General secondary education

Junior agricultural education

Junior technical education

Junior transport, communication and traffic education

Junior medical and paramedical education

Lower business education, secondary school for

tradesmen (lower level), practical training for clerks

and salesmen at the school for domestic science and

technique training for clerks and salesmen

391 Business security and surveillance training

Secondary education, higher level

401 General secondary education, intermediate and

higher levels

Training for driving instructor, sports coach

Senior agricultural education

Senior school for laboratory science

Senior technical training

Senior education in transportation, communication

and traffic science

Training of nurses and medical receptionists at the

secondary school for medical and other services

Secondary school for medical laboratory science,

higher level

Training for medical clerks, etc.
Training for ward orderlies, etc.

Senior retail school and intermediate business education

(1)

26

13

7
-27

14

34

18

19

18

12

32
25

$-14$

Intermediate business education, department of

management studies

Social work and welfare work (secondary school for medical

and other services )

External care, services as taught at the secondary school for medical and other services or the INTAS

Secondary hotel and catering school, hairdresser's school

Fashion drawing, etc.

Higher vocational education

506 Training college for primary and pre-primary school

teachers, secondary-school teacher training, new style

Training for interpreters and translators

Training for pastoral work, etc.

Agricultural college

Laboratory college

Technical college

Transport, communication and traffic college

Nursing college, physiotherapy college

College for medical laboratory science

Dietetics college, etc.

Business science college, exclusive of administrative

and fiscal studies

Courses for ergonomists and management science at

the higher technical school, etc

Business science college, legal and administrative studies

College of social studies, library studies

Hotel college

Art academy, academy of dramatic art

Scientific education

Teacher training (highest level)

Language and literature

Theology

Agricultural and domestic sciences

Mathematics and physics

Technical sciences

Medical sciences

Pharmacy

Economics and business administration (B.A.)
Econometrics, actuary and management (B.Sc.)

Law

Socio-cultural sciences

Fine arts

$\begin{array}{rrr}2 & 11 & 14 \\ 13 & 11 & 24 \\ -4 & 15 & 11 \\ 13 & 12 & 25 \\ 22 & 12 & 34 \\ 19 & 11 & 30 \\ 21 & 11 & 32 \\ 159 & 10 & 169 \\ 32 & 13 & 45 \\ 212 & 12 & 224 \\ 9 & 11 & 20 \\ -7 & 11 & 4 \\ 18 & 12 & 30\end{array}$


Table 11. Quotient of supply and demand by educational group, 1985-1992

\begin{tabular}{|c|c|c|c|}
\hline code & educational group & quotient & $\begin{array}{c}\text { qualification } \\
\text { labour market prospects }\end{array}$ \\
\hline
\end{tabular}

Secondary education, lower level

$\begin{array}{ll}301 & \text { General secondary education } \\ 321 & \text { Junior agricultural education } \\ 331 & \text { Junior technical education } \\ 341 & \text { Junior transport, communication and traffic education } \\ 351 & \text { Junior medical and paramedical education } \\ 361 & \text { Lower business education, secondary school for tradesmen } \\ & \text { (lower level), practical training for clerks and salesmen at the } \\ & \text { school for domestic science and technique }\end{array}$

0.52

1.13

1.00

$-2.07$

0.08

School for domestic science and technique exclusive of training

for clerks and salesmen

Business security and surveillance training

Secondary education, higher level

General secondary education, intermediate and higher levels

Training for driving instructor, sports coach

Senior agricultural education

Senior school for laboratory science

Senior technical training

Senior education in transportation, communication

and traffic science

Training of nurses and medical receptionists at the

secondary school for medical and other services

Secondary school for medical laboratory science, higher level

Training for medical clerks, etc.

Training for ward orderlies, etc.

Senior retail school and intermediate business education

Intermediate business education, department of

management studies

Social work and welfare work (secondary school for medical

and other services )

External care, services as taught at the secondary school for medical and other services or the INTAS

Secondary hotel and catering school, hairdresser's school

Fashion drawing, etc.

good

reasonable

good

very poor

good

very poor

good

poor

poor

moderate

good

reasonable

reasonable

good

reasonable

good

moderate

reasonable

good

good

moderate

reasonable

good

very poor

Higher vocational education

Training college for primary and pre-primary school teachers,

secondary-school teacher training, new style

very poor

poor

good

moderate

good

reasonable

good

moderate

reasonable

reasonable

College for medical laboratory science

Business science college, exclusive of administrative

and fiscal studies

good

good

good

very poor

good

very poor

Hotel college

Art academy, academy of dramatic art

0.84

$-7.75$

Scientific education

Teacher training (highest level)

Language and literature

Agricultural and domestic sciences $\quad 4.12$

$\begin{array}{ll}\text { Technical sciences } & 1.60\end{array}$

Medical sciences $\quad 1.41$

Pharmacy $\quad 0.74$

Economics and business administration (B.A.) $\quad 1.96$

Econometrics, actuary and management (B.Sc.) 0.47

4.75

$\begin{array}{lr}\text { Socio-cultural sciences } & 22.50\end{array}$

Fine arts

poor
poor
reasonable
poor
reasonable
reasonable
reasonable
good
reasonable
good
poor
very poor
poor




\section{RISK INDICATORS}

\subsection{Introduction}

As pointed out in the first chapter, we are developing, besides labour market forecasts also labour market indicators from historical data. These complementary indicators are meant as an extra dimension for the future prospects ascribed to educational groups. In a previous ROA working document by De Grip and Heijke (1988), an inventory was made of various types of labour market indicators, their target groups, and the data requirements. In the present report we will refer only to indicators which supplement the forecasts of supply and demand by pointing out the uncertainty besetting the labour market prospects of certain occupations or educational groups. These so-called risk indicators are: the sensitiveness of the employment in the occupations to the business cycle, the potential mobility which an occupation has into other business sectors, and the potential mobility of educational groups into other occupations and business sectors.

These indicators are a criterion of the job security and flexibility of the occupation or the educational group on the labour market. From these indicators can be derived, for instance, whether an educational group trains for just one occupation which moreover occurs almost uniquely in a highly cycle-sensitive sector, or, on the contrary, has many alternatives to become employed in other occupations and sectors whose employment is moreover little sensitive to the business cycle. Section 6.2 treats of cyclical sensitivity by occupation, and section 6.3 discusses the dispersion indicator for occupations and educational groups.

\subsection{Sensitivity to the business cycle}

The forecasts of supply and demand on the labour market represent medium-term estimates that are neutral with respect to the business cycle. To investigate the cyclical sensitivity of separate sectors, the reaction of employment to cyclical fluctuations in the past can be checked. To that end, we have followed the example of the NEI (1972) in constructing a fluctuation index. The formula reads as follows:

$$
F I_{S}=\frac{100}{H} \sum_{h=1}^{\mathrm{H}} \underset{\mathrm{T}_{\text {St }}}{\mid \mathrm{F}_{S t} \perp}
$$


$\mathrm{FI}_{\mathbf{S}}=$ fluctuation index sector $\mathrm{s}$

$\mathrm{H}=$ number of years observed

$\mathrm{F}_{\mathrm{St}}=$ dispersion from the trend of employment growth

$\mathrm{T}_{\mathrm{st}}=$ the trend of employment development

The trend development of employment is established by taking the five-year progressive mean of employment $\mathrm{E}_{\mathbf{S t}}$ :

2

$\mathrm{T}_{\mathrm{St}}=[1 / 5] \Sigma \mathrm{E}_{\mathrm{St}+\mathrm{h}}$ $h=-2$

The deviation from the trend, $F_{\text {st }}$, is then calculated as the absolute difference between employment $\mathrm{E}_{\mathbf{S t}}$ and the trend $\mathrm{T}_{\mathbf{S t}}$.

The fluctuation indexes of the sectors are calculated over the 1950-1988 period. The index for each occupational class is established by weighting the sectoral indexes with the share of that occupational class in sectoral employment in 1985:

$\mathrm{FI}_{\mathrm{O}}=\underset{S=1}{\mathrm{~S}} \mathrm{a}_{\mathrm{OS}} \mathrm{FI}_{\mathrm{S}}$

where:

$\mathrm{FI}_{\mathrm{O}}=$ fluctuation index occupation 0

$a_{O S}=$ the share of occupation $O$ in sectoral employment

This calculating method assumes that employment fluctuates equally in all occupations within a sector of industry, an assumption that may be refuted in practice $^{4}$. However, we lack the long time series of employment by sector and occupation that would be required for a more sophisticated index. Tables $12 \mathrm{a}$ and $12 \mathrm{~b}$ present the ten occupational classes with the widest and narrowest employment fluctuations. For a complete survey of employment fluctuations per occupational class, consult annex 1.

4. Compare the estimation results of the utilization rate variable in the occupational mode1 (Dekker, De Grip, Heijke 1988). 
Table 12a. Occupational classes with the most cyclical sensitivity (1950-1988)

\begin{tabular}{llc}
\hline code & occupational class & FIo\% \\
\hline & & 38 \\
71 & Miners, quarrymen, well drillers and related workers & 21 \\
95 & Bricklayers, carpenters and other construction workers & 19 \\
83 & Blacksmiths, toolmakers and machine tool operators & 19 \\
93 & Painters & 18 \\
72 & Metal processors & 18 \\
87 & Plumbers, welders, sheet metal and structural metal preparers and erectors & 17 \\
85 & Electrical fitters and related electric and electronics workers & 17 \\
99 & Labourers n.e.c. & 16 \\
70 & Production supervisors and general foremen & 16 \\
74 & Chemical processors and related workers & \\
\hline
\end{tabular}

Source: ROA

Table 12b. Occupational classes with the least cyclical sensitivity (1950-1988)

\begin{tabular}{llc}
\hline code & occupational class & FIo\% \\
\hline & & \\
61 & Farmers & 4 \\
64 & Fishermen, hunters and related workers & 4 \\
06 & Medical, dental, veterinary and related workers & 5 \\
62 & Agricultural and animal husbandry workers & 5 \\
05 & Life scientists and related technicians & 6 \\
13 & Teachers & 6 \\
51 & Working proprietors (catering and lodging services) & 6 \\
57 & Hairdressers, barbers, beauticians related workers & 6 \\
59 & Service workers n.e.c. & 6 \\
60 & Farm managers and supervisors & 6 \\
\hline
\end{tabular}

Source: ROA

Among the occupations that are most sensitive to the business cycle, are many industrial occupations; service occupations, on the contrary, appear to be relatively stable.

\subsection{Dispersion indicator}

For the purpose of developing an indicator to measure the flexibility on the labour market, we distinguish between occupational and industrial alternatives for educational groups and industrial alternatives for occupations. The idea to determine for each educational group an indication of alternatives among occupations, springs from the opinion that there is no unique link between occupation and education (Van Hoof and Dronkers, 1980). On the other hand the 
expectation is warranted that the occupational flexibility may vary widely among the educational groups $^{5}$.

The labour market flexibility of educational groups and occupations can be charted with the help of dispersion criteria. Indeed, the wider the dispersion, the greater the flexibility on the labour market. Warnken (1986) developed a criterion indicative of the existing flexibility on the labour market: the 'Gini-Hirschman' coefficient. The formula for the occupational spread of educational group $d$ reads as follows :

$\mathrm{GH}_{\mathrm{d}}=\left(1-\sum_{\mathrm{O}=1}^{0} \alpha_{\mathrm{do}}{ }^{2}\right) \cdot[0 /(0-1)]$

\footnotetext{
$\alpha_{\mathrm{do}}=$ share of discipline $\mathrm{d}$ in occupational employment $\left.\underset{\mathrm{O}}{\left(\sum\right.} \alpha_{\mathrm{do}}=1\right)$

$0=$ number of occupations
}

The indicator is equal to 0 when a educational group occurs in one occupation only, and equal to 1 when the educational group is distributed evenly among all occupations. The formulas for the sectoral dispersion of occupations and educational groups can be determined in a similar way.

By analogy of the Gini coefficient, the Gini-Hirschman coefficient is interpreted as follows. There are 0 situations in which a person may find himself. If that person is placed in a random new situation, drawn from the existing distribution among all possible situations, he may end up either in the same or in a different situation. The same situation has a 'yield' of 0 ; a different situation has a 'yield' of 1 . The Gini-Hirschman coefficient thus indicates the average chance of landing in a different situation.

The above interpretation highlights out three important assumptions incorporated in the Gini-Hirschman coefficient. The first is that the difference between two situations is equivalent. The second is that the yield is 0 if a person is allotted the same situation as before. The third is that there are no differences within one group. The last assumption implies relevance of the aggregation level to which the

5. The importance of combining labour market forecasts with flexibility data has been discussed in some detail in De Grip and Heijke (1989). 
dispersion criterion refers. Actually, equation 10 corrects to some extent for the aggregation level by multiplication by the term $[0 /(0-1)]$.

Tables $13 \mathrm{a}$ and $13 \mathrm{~b}$ present the occupations with the widest and narrowest sectoral dispersion. Especially with executive and clerical occupations the sectoral dispersion is wide. Occupational classes with a narrow dispersion among branches mostly refer to self-employed in a certain sector of activity, or to workers and those employed in the public sector. A complete survey of sectoral dispersion by occupational class can be found in annex 2 .

Tables $14 \mathrm{a}$ and 14b present, respectively, the educational groups with the widest and narrowest occupational dispersion. Tables $15 \mathrm{a}$ and $15 \mathrm{~b}$ give the widest and narrowest sectoral dispersions by educational group. Annexes 3 and 4 give the respective overall surveys.

Predictably, institutions of general education can be observed from the tables to have a wide occupational dispersion. The same can be said of technical and clerical (lower and higher secondary) educational groups. Somewhat surprising is the wide occupational dispersion of educational groups coming under code 481: external care, medical and other services, INTAS; mark, however, that these educational groups are an umbrella for several widely varying courses for personal-service occupations (family care, hairdresser, dual education for personal-care occupations). Except for two non-regular courses, all educational groups with a narrow occupational dispersion are on the secondary and higher levels. Once more, we find courses training specifically for certain public-sector occupations.

The pattern just sketched of educational groups with wide and narrow sectoral dispersions appears to be largely in agreement with that of educational groups with extreme occupational dispersion. For educational groups with a narrow dispersion that could be explained from the fact that they train for a specific occupation only occurring in one sector. For educational groups with a wide sectoral dispersion several explanations suggest themselves. A programme may train either for one occupation occurring in several sectors, or for several occupations each occurring in one or more sectors. To make a relevant distinction, the sectoral dispersion by educational group must be related to occupational dispersion by educational group.

With respect to the refuge opportunities and the sensitiveness of the indicator to the degree of aggregation, a qualifying remark is in order. The fact is that while occupations and educational groups in the public sector can be adequately 
distinguished, some specialist industrial or service occupations and educational groups are missing from the table of low scorers on dispersion. Presumably the reason is that in the 2-digit occupational classification, such public occupations as civil servant, executive officer in public administration, police officer and teacher carry a separate code. The question arises whether the 2-digit classification is distinctive enough, or whether the aggregation as such entails too broad a division of occupational classes.

Combining the dispersion criterion and the cyclical sensitiveness of occupations we find for teaching staff both a narrow dispersion in table $13 \mathrm{~b}$ and low sensitiveness in table 12b. The example indicates that these indicators should related to each other (and to the forecasts), as is indeed done in I-See!.

Table 13a. Occupational classes with the highest sectoral dispersion (average 1979-1985)

\begin{tabular}{llc}
\hline code & occupational class & GHo \\
& & 0.96 \\
21 & Managing and higher executive functions exclusive of public administration & 0.93 \\
02 & Architects, engineers and related technicians & 0.93 \\
32 & Stenographers, typists and card- and tape-punching machine operators & 0.93 \\
34 & Computing machine operators & 0.93 \\
97 & Material handling and related equipment operators, dockers and freight handlers & 0.92 \\
09 & Economists & 0.92 \\
39 & Clerical and related workers n.e.c. & 0.92 \\
70 & Production supervisors and general foremen & 0.91 \\
38 & Telephone and telegraph operators & 0.91 \\
84 & Machinery fitters, machine assemblers and precision-instrument makers (except electrical) & \\
\hline
\end{tabular}

Source: ROA

Table 13b. Occupational classes with the lowest sectoral dispersion (average 1979-1985)

code occupational class $\mathrm{GH}_{\mathrm{O}}$

$\begin{array}{lll}43 & \text { Shopkeepers, street vendors } & 0.00 \\ 61 & \text { Farmers } & 0.00 \\ 40 & \text { Managers (wholesale) } & 0.01 \\ 41 & \text { Managers (retail trade) } & 0.01 \\ 42 & \text { Working proprietors (wholesale) } & 0.01 \\ 57 & \text { Hairdressers, barbers, beauticians related workers } & 0.07 \\ 13 & \text { Teachers } & 0.09 \\ 20 & \text { Legislative officials and government administrators } & 0.09 \\ 31 & \text { Government executive officials } & 0.12 \\ 64 & \text { Fishermen, hunters and related workers } & 0.14\end{array}$


Table 14a. Educational groups with the highest occupational dispersion (average 1979-1985)

$\begin{array}{lll}\text { code } \quad \text { educational group } & \mathrm{GH}_{\mathrm{d}}\end{array}$

$331 \quad$ Junior technical education 0.95

436 Senior technical training $\quad 0.95$

$301 \quad$ General secondary education $\quad 0.93$

441 Senior education in transportation, communication and traffic science 0.93

$461 \quad$ Senior retail school and intermediate business education $\quad 0.93$

401 General secondary education, intermediate and higher levels $\quad 0.92$

361 Lower business education, secondary school for tradesmen (lower level), practical training for $\begin{array}{ll}\text { clerks and salesmen at the school for domestic science and technique } & 0.91 \\ \text { School for domestic science and technique exclusive of training for clerks and salesmen } & 0.91\end{array}$

$\begin{array}{lll}381 & \text { School for domestic science and technique exclusive of training for clerks and salesmen } & 0.91\end{array}$

$\begin{array}{lll}561 & \text { Business science college, exclusive of administrative and fiscal studies } & 0.90\end{array}$

Source: ROA

Table 14b. Educational groups with the lowest occupational dispersion (avarage 1979-1985)

\begin{tabular}{lll}
\hline code & educational group & $\mathrm{GH}_{\mathrm{d}}$ \\
\hline & & 0.22 \\
651 & Medical sciences & 0.26 \\
606 & Teacher training (highest level) & 0.29 \\
551 & Nursing college, physiotherapy college & 0.36 \\
454 & Training for ward orderlies, etc. & 0.37 \\
506 & Training college for primary and pre-primary school teachers, & 0.41 \\
& secondary-school teacher training, new style & 0.42 \\
516 & Training for pastoral work, etc. & 0.49 \\
391 & Business security and surveillance training & 0.50 \\
616 & Theology & 0.51 \\
652 & Pharmacy & \\
451 & Training of nurses and medical receptionists at the secondary school for medical & \\
& and other services & \\
\hline
\end{tabular}


Table 15a. Educational groups with the highest sectoral dispersion (average of 1979-1985)

\begin{tabular}{lll}
\hline code & educational group & $\mathrm{GH}_{\mathbf{d}}$ \\
\hline & & 0.94 \\
301 & General secondary education & 0.94 \\
401 & General secondary education, intermediate and higher levels & 0.94 \\
436 & Senior technical training & 0.93 \\
331 & Junior technical education & 0.91 \\
361 & Lower business education, secondary school for tradesmen (lower level), practical training for & 0.90 \\
& clerks and salesmen at the school for domestic science and technique & 0.90 \\
431 & Senior school for laboratory science & 0.89 \\
531 & Laboratory college & 0.89 \\
381 & School for domestic science and technique exclusive of training for clerks and salesmen & 0.88 \\
461 & Senior retail school and intermediate business education & \\
636 & Technical sciences & \\
\end{tabular}

Source: ROA

Table 15b. Educational groups with the lowest sectoral dispersion (average of 1979-1985)

\begin{tabular}{llc}
\hline code & educational group & GHd \\
\hline & & 0.26 \\
606 & Teacher training (highest level) & 0.26 \\
651 & Medical sciences & 0.33 \\
551 & Nursing college, physiotherapy college & 0.34 \\
506 & Training college for primary and pre-primary school teachers, & 0.36 \\
& secondary-school teacher training, new style & 0.38 \\
466 & Intermediate business education, department of management studies & 0.39 \\
516 & Training for pastoral work, etc. & 0.41 \\
552 & College for medical laboratory science & 0.45 \\
451 & Training of nurses and medical receptionists at the secondary school for & 0.46 \\
& medical and other services & \\
\hline
\end{tabular}




\section{CONCLUSION}

With respect to medium-term forecasts, the present report records some improvements on those of 1987. The models have been given a sounder theoretical foundation. Besides, for the first time a survey of the labour market has been drawn up which covers all educational groups. The collection of data is still fraught with problems, however, so that 1985-1992 had to be maintained as forecasting period. The short observation period made it necessary for us to pool the data without being able to verify adequately the stability of parameters through time and across sectors of activity. Moreover, the classifications used, especially for occupational classes, frequently appear not to coincide with actually existing labour market segments.

To complete the information system, our two-track approach - to start at once drawing up forecasts and gradually acquire better data and models - seems a successful one. For instance, a portion of the information could be instantly incorporated in I-See!. The linking with I-See! enables us to take the wishes of users into account in the further development of the ROA information system, with respect to the contents as well as the style of the labour market information.

The development and application of models to forecast extension demand by occupational class and educational group represent methodical enlargement. The search is continued for econometrically consistent models to forecast extension demand, capable of taking into account specific demands ensuing from data and econometrical restrictions. In particular, the influence of working hours on the occupational pattern will be incorporated more explicitly in the occupational model (see Groot and Heijke 1989). The modelling of replacement demand will also be improved. Additional data on replacement demand have already been collected; unfortunately it has not been possible to obtain more recent relevant data from the Labor Force Inquiry (LFI, started 1987). For a better modelling of employment in occupational classes, LFI data may perhaps be useful, even though they seem to be discontinuous with respect to the data from the labour-force censuses (held until 1985).

Unless data shortages intervene, the forecasting period will be moved to the 19901994 period as from 1991. We will then verify whether a new classification of occupations, better matching the existing labour market segments, can be implemented. As the information system is extended, new labour market indicators will be looked for, and the feasibility of further regionalizing of the information checked. 


\section{LITERATURE}

Beekman, Th.B.J., R.J.P. Dekker, A. de Grip, J.A.M. Heijke (1989), An Explanation of the Educational Structure of Occupations, ROA-W-1989/3E, Maastricht.

Bureau of Labor Statistics (1988), Occupational outlook quarterly, Vo1. 32, Nr. 2, U.S. Department of Labor, Washington D.C.

Centraal Bureau voor de Statistiek (1985), Beroepenclassificatie 1984, Voorburg.

Centraal Bureau voor de Statistiek (1986), Standaard Onderwijs Indeling 1978, Voorburg.

Centraal Planbureau (1989), Centraal Economisch Plan, 's-Gravenhage.

Centraal Planbureau (1989), Macro Economische Verkenning 1990, waarin opgenomen een macro-economische verkenning voor de periode 1991-1994, 's-Gravenhage.

Dekker, R.J.P., A. de Grip, J.A.M. Heijke (1988), An Explanation of the Occupational Structure of Sectors of Industry, ROA-W-1988/2E, Maastricht.

Grip, A. de, (1987), Onderwijs en Arbeidsmarkt: Scholingsdiscrepanties, VUuitgeverij, Amsterdam.

Grip, A. de, J.A.M. Heijke (1988), Labour Market Indicators: an Inventory, ROA-W1988/1E, Maastricht.

Grip, A. de, L.F.M. Groot, J.A.M. Heijke (1987), Clustering occupational classes by educational structure, ROA-W-1987/2E, Maastricht.

Grip, A. de, J.A.M. Heijke (1989), Het flexibiliteitspotentieel van universitaire studierichtingen, Tijdschrift voor Arbeidsvraagstukken, jaargang $5 \mathrm{nr}$. 4, pp. 6981 .

Grip, A. de, J.A.M. Heijke, R.J.P. Dekker, L.F.M. Groot (1987), De arbeidsmarkt naar beroep in 1992 en de positie van academici daarbinnen, ROA-W-1987/1, Maastricht.

Grip, A. de, J.A.M. Heijke, R.J.P. Dekker, Th.B.J. Beekman, H.M.M. Peeters (1989), De arbeidsmarktperspectieven van beroepsklassen en opleidingstypen in 1992, rapportage I-See!, ROA-R-1989/7, Maastricht.

Groot, L.F.M., J.A.M. Heijke, (1989), Een verklaring van arbeidsduur en deeltijdarbeid naar beroep en bedrijfstak, ROA-W-1989/2, Maastricht.

Hoof, J.J. van, J. Dronkers (1980), Onderwijs en arbeidsmarkt; een verkenning van de relaties tussen onderwijs, arbeidsmarkt en arbeidssysteem, Van Loghum Slaterus, Deventer.

Kuhry, B., H.E. Ruitenberg, R.M. Spronk (1986), De onderwijsprognose 1986. Leerlingen, schoolverlaters en bevolking naar opleidingsniveau tot 2000. (SKILL), Werkdocument 9, Centraal Planbureau, 's-Gravenhage.

Nederlands Economisch Instituut (1972), Bouwnijverheid: planning, groei en fluctuaties, deel II: fluctuaties, Rotterdam.

ROA (1989), Naar een informatiesysteem onderwijs-arbeidsmarkt, onderzoeksprogramma 1989/1990, ROA-R-1989/1, Maastricht. 
Ruitenberg, H.E. (1989), Tijdreeksen uit de onderwijsprognoses 1989-1, Centraal Planbureau, Hoofdafdeling II, Afdeling Arbeid, Notitienummer 15, 's-Gravenhage.

Taakgroep Studentenramingen (1988), Wetenschappelijke Onderwijs Ramingen Studenten Aantallen (WORSA 1988), 's-Gravenhage.

Taakgroep Studentenramingen (1988), Raming Hoger Beroepsonderwijs Studentenaantallen (RHOBOS 1988), 's-Gravenhage.

Warnken, J. (1986), Zur Entwicklung der 'Internen" Anpassungfähigkeit der Berufe bis zum Jahre 2000. Projektionen unter den Annahmen der Wachstumszenarien der Prognos-Studie, Mitteilingen aus der Arbeitsmarkt- und Berufsforschung, nr. 1 , pp. 119-133. 
ANNEX 1. Overall review of cyclical sensitivity by occupational class (fluctuation index FI)

\begin{tabular}{lll}
\hline Code Name & FI \\
\hline
\end{tabular}

\begin{tabular}{|c|c|c|}
\hline 01 & Physical scientists and related technicians & 9.9 \\
\hline 02 & Architects, engineers and related technicians & 13.6 \\
\hline 04 & Aircraft and ship's officers & 13.5 \\
\hline 05 & Life scientists and related technicians & 6.3 \\
\hline 06 & Medical, dental, veterinary and related workers & 5.4 \\
\hline 08 & Statisticians, mathematicians and related technicians & 9.8 \\
\hline 09 & Economists & 9.1 \\
\hline 11 & Accountants & 6.8 \\
\hline 12 & Jurists & 7.2 \\
\hline 13 & Teachers & 6.5 \\
\hline 14 & Workers in religion & 7.0 \\
\hline 15 & Authors, journalists and related workers & 9.3 \\
\hline 16 & Sculptors, painters, photographers and related creative artists & 8.0 \\
\hline 17 & Composers and performing artists & 7.1 \\
\hline 18 & Athletes, sportsmen and related workers & 7.0 \\
\hline 19 & Professional, technical and related workers n.e.c. & 7.3 \\
\hline 20 & Legislative officials and government administrators & 6.6 \\
\hline 21 & Managing and higher executive functions exclusive of public administration & 12.9 \\
\hline 30 & Clerical supervisors & 9.0 \\
\hline 31 & Government executive officials & 6.7 \\
\hline 32 & Stenographers, typists and card- and tape-punching machine operators & 9.0 \\
\hline 33 & Bookkeepers, cashiers and related workers & 9.1 \\
\hline 34 & Computing machine operators & 10.1 \\
\hline 35 & Transport and communications supervisors & 11.1 \\
\hline 36 & Transport conductors & 10.4 \\
\hline 37 & Mail distribution clerks & 9.9 \\
\hline 38 & Telephone and telegraph operators & 9.6 \\
\hline 39 & Clerical and related workers n.e.c. & 9.3 \\
\hline 40 & Managers (wholesale) & 6.8 \\
\hline 41 & Managers (retail trade) & 6.8 \\
\hline 42 & Working proprietors (wholesale) & 6.8 \\
\hline 43 & Shopkeepers, street vendors & 6.8 \\
\hline 45 & Sales supervisors and buyers & 9.1 \\
\hline 46 & Technical salesmen, commercial travellers and manufacturer's agents & 9.1 \\
\hline 47 & Insurance, real estate, securities and business services, salesmen and auctioneers & 10.2 \\
\hline 48 & Salesmen, shop assistants and related workers & 7.2 \\
\hline 50 & Managers (catering and lodging services) & 8.4 \\
\hline 51 & Working proprietors (catering and lodging services) & 6.3 \\
\hline 52 & Housekeeping and related service supervisors & 6.8 \\
\hline 53 & Cooks, waiters, bartenders and related workers & 7.1 \\
\hline 54 & Maids and related housekeeping workers n.e.c. & 7.0 \\
\hline 55 & Building caretakers, charworkers, cleaners and related workers & 7.6 \\
\hline 56 & Launderers, dry-cleaners and pressers & 7.0 \\
\hline 57 & Hairdressers, barbers, beauticians related workers & 6.3 \\
\hline 58 & Protective service workers & 7.4 \\
\hline 59 & Service workers n.e.c. & 6.4 \\
\hline 60 & Farm managers and supervisors & 6.1 \\
\hline 61 & Farmers & 3.8 \\
\hline 62 & Agricultural and animal husbandry workers & 5.4 \\
\hline 63 & Forestry workers & 8.1 \\
\hline 64 & Fishermen, hunters and related workers & 4.3 \\
\hline 70 & Production supervisors and general foremen & 15.8 \\
\hline 71 & Miners, quarrymen, well drillers and related workers & 37.6 \\
\hline 72 & Metal processors & 18.3 \\
\hline 73 & Wood preparation workers and paper makers & 10.9 \\
\hline 74 & Chemical processors and related workers & 15.9 \\
\hline 75 & Spinners, weavers, knitters, dyers and related workers & 16.2 \\
\hline
\end{tabular}


Tobacco preparers and tobacco-product makers

Tailors, dressmakers, sewers, upholsterers and related workers $\quad 13.8$

Shoemakers and leather goods makers 14.3

Cabinetmakers, woodworkers and related workers $\quad 14.6$

Blacksmiths, toolmakers and machine tool operators $\quad 18.8$

Machinery fitters, machine assemblers and precision-instrument makers (except electrical) $\quad 12.5$

Electrical fitters and related electric and electronics workers $\quad \mathbf{1 2 . 5}$

Broadcasting station and sound equipment operators and cinema projectionists $\quad 7.0$

Plumbers, welders, sheet metal and structural metal preparers and erectors $\quad 17.8$

Jewellery and precious metal workers $\quad 12.9$

Glass formers, potters and related workers $\quad 15.0$

Rubber and plastics product makers $\quad 14.0$

Paper and paperboard product makers $\quad 11.2$

Printers and related workers $\quad 11.5$

Painters $\quad 19.1$

Production and related workers n.e.c. $\quad 14.0$

Bricklayers, carpenters and other construction workers $\quad \mathbf{2 1 . 0}$

Stationary engine and related equipment operators $\quad \mathbf{1 1 . 5}$

Material handling and related equipment operators, dockers and freight handlers $\quad 11.6$

$\begin{array}{lc}\text { Transport equipment operators } & 10.2\end{array}$

Labourers n.e.c. $\quad 17.3$ 


\begin{tabular}{lll}
\hline Code Name & GH \\
\hline
\end{tabular}

\begin{tabular}{|c|c|c|}
\hline 01 & Physical scientists and related technicians & 0.90 \\
\hline 02 & Architects, engineers and related technicians & 0.93 \\
\hline 04 & Aircraft and ship's officers & 0.57 \\
\hline 05 & Life scientists and related technicians & 0.72 \\
\hline 06 & Medical, dental, veterinary and related workers & 0.30 \\
\hline 08 & Statisticians, mathematicians and related technicians & 0.90 \\
\hline 09 & Economists & 0.92 \\
\hline 11 & Accountants & 0.27 \\
\hline 12 & Jurists & 0.70 \\
\hline 13 & Teachers & 0.09 \\
\hline 14 & Workers in religion & 0.19 \\
\hline 15 & Authors, journalists and related workers & 0.82 \\
\hline 16 & Sculptors, painters, photographers and related creative artists & 0.80 \\
\hline 17 & Composers and performing artists & 0.18 \\
\hline 18 & Athletes, sportsmen and related workers & 0.16 \\
\hline 19 & Professional, technical and related workers n.e.c. & 0.73 \\
\hline 20 & Legislative officials and government administrators & 0.09 \\
\hline 21 & Managing and higher executive functions exclusive of public administration & 0.96 \\
\hline 30 & Clerical supervisors & 0.81 \\
\hline 31 & Government executive officials & 0.12 \\
\hline 32 & Stenographers, typists and card- and tape-punching machine operators & 0.93 \\
\hline 33 & Bookkeepers, cashiers and related workers & 0.89 \\
\hline 34 & Computing machine operators & 0.93 \\
\hline 35 & Transport and communications supervisors & 0.79 \\
\hline 36 & Transport conductors & 0.05 \\
\hline 37 & Mail distribution clerks & 0.46 \\
\hline 38 & Telephone and telegraph operators & 0.91 \\
\hline 39 & Clerical and related workers n.e.c. & 0.92 \\
\hline 40 & Managers (wholesale) & 0.01 \\
\hline 41 & Managers (retail trade) & 0.01 \\
\hline 42 & Working proprietors (wholesale) & 0.01 \\
\hline 43 & Shopkeepers, street vendors & 0.00 \\
\hline 45 & Sales supervisors and buyers & 0.57 \\
\hline 46 & Technical salesmen, commercial travelles and manufacturer's agents & 0.63 \\
\hline 47 & Insurance, real estate securities and business services, salesmen and auctioneers & 0.63 \\
\hline 48 & Salesmen, shop assistants and related workers & 0.29 \\
\hline 50 & Managers (catering and lodging services) & 0.63 \\
\hline 51 & Working proprietors (catering and lodging services) & 0.01 \\
\hline 52 & Housekeeping and related service supervisors & 0.76 \\
\hline 53 & Cooks, waiters, bartenders and related workers & 0.71 \\
\hline 54 & Maids and related housekeeping workers n.e.c. & 0.41 \\
\hline 55 & Building caretakers, charworkers, cleaners and related workers & 0.79 \\
\hline 56 & Launderers, dry-cleaners and pressers & 0.33 \\
\hline 57 & Hairdressers, barbers, beauticians related workers & 0.07 \\
\hline 58 & Protective service workers & 0.41 \\
\hline 59 & Service workers n.e.c. & 0.65 \\
\hline 60 & Farm managers and supervisors & 0.43 \\
\hline 61 & Farmers & 0.00 \\
\hline 62 & Agricultural and animal husbandry workers & 0.31 \\
\hline 63 & Forestry workers & 0.57 \\
\hline 64 & Fishermen, hunters and related workers & 0.14 \\
\hline 70 & Production supervisors and general foremen & 0.92 \\
\hline 71 & Miners, quarrymen, well drillers and related workers & 0.62 \\
\hline 72 & Metal processors & 0.65 \\
\hline 73 & Wood preparation workers and paper makers & 0.52 \\
\hline 74 & Chemical processors and related workers & 0.52 \\
\hline 75 & Spinners, weavers, knitters, dyers and related workers & 0.32 \\
\hline 77 & Food and beverage processors & 0.36 \\
\hline 78 & Tobacco preparers and tobacco-product makers & 0.01 \\
\hline
\end{tabular}


79 Tailors, dressmakers, sewers, upholsterers and related workers $\quad 0.70$

$80 \quad$ Shoemakers and leather goods makers $\quad 0.52$

81 Cabinetmakers, woodworkers and related workers $\quad 0.53$

83 Blacksmiths, toolmakers and machine tool operators $\quad 0.58$

84 Machinery fitters, machine assemblers and precision-instrument makers (except electrical) $\quad 0.91$

$85 \quad$ Electrical fitters and related electric and electronics workers 0.88

86 Broadcasting station and sound equipment operators and cinema projectionists $\quad 0.56$

87 Plumbers, welders, sheet metal and structural metal preparers and erectors 0.80

$88 \quad$ Jewellery and precious metal workers $\quad 0.51$

$89 \quad$ Glass formers, potters and related workers $\quad 0.35$

$90 \quad$ Rubber and plastics product makers $\quad 0.34$

$91 \quad$ Paper and paperboard product makers $\quad 0.23$

$92 \quad$ Printers and related workers $\quad 0.49$

93 Painters $\quad 0.54$

$94 \quad$ Production and related workers n.e.c. $\quad 0.85$

95 Bricklayers, carpenters and other construction workers $\quad 0.28$

96 Stationary engine and related equipment operators $\quad 0.87$

97 Material handling and related equipment operators, dockers and freight handlers 0.93

98 Transport equipment operators 0.68

$99 \quad$ Labourers n.e.c. $\quad 0.72$ 


\begin{tabular}{|c|c|c|}
\hline Code & Name & GH \\
\hline 301 & General secondary education & 0.93 \\
\hline 321 & Junior agricultural education & 0.74 \\
\hline 331 & Junior technical education & 0.95 \\
\hline 341 & Junior transport, communication and traffic education & 0.78 \\
\hline 351 & Junior medical and paramedical education & 0.80 \\
\hline 361 & $\begin{array}{l}\text { Lower business education, secondary school for tradesmen (lower level), practical } \\
\text { training for clerks and salesmen at the school for domestic science and technique }\end{array}$ & 0.91 \\
\hline 381 & School for domestic science and technique exclusive of training for clerks and salesmen & 0.91 \\
\hline 391 & Business security and surveillance training & 0.42 \\
\hline 401 & General secondary education, intermediate and higher levels & 0.92 \\
\hline 406 & Training for driving instructor, sports coach & 0.70 \\
\hline 421 & Senior agricultural education & 0.76 \\
\hline 431 & Senior school for laboratory science & 0.80 \\
\hline 436 & Senior technical training & 0.95 \\
\hline 441 & Senior education in transportation, communication and traffic science & 0.93 \\
\hline 451 & $\begin{array}{l}\text { Training of nurses and medical receptionists at the secondary school } \\
\text { for medical and other services }\end{array}$ & 0.51 \\
\hline 452 & Secondary school for medical laboratory science, higher level & 0.67 \\
\hline 453 & Training for medical clerks, etc. & 0.63 \\
\hline 454 & Training for ward orderlies, etc. & 0.36 \\
\hline 461 & Senior retail school and intermediate business education & 0.93 \\
\hline 466 & Intermediate business education, department of management studies & 0.75 \\
\hline 471 & Social work and welfare work (secondary school for medical and other services) & 0.82 \\
\hline 481 & $\begin{array}{l}\text { External care, services as taught at the secondary school for medical and other } \\
\text { services or the INTAS }\end{array}$ & 0.86 \\
\hline 483 & Secondary hotel and catering school, hairdresser's school & 0.82 \\
\hline 486 & Fashion drawing, etc. & 0.84 \\
\hline 506 & $\begin{array}{l}\text { Training college for primary and pre-primary school teachers, secondary-school } \\
\text { teacher training, new style }\end{array}$ & 0.37 \\
\hline 511 & Training for interpreters and translators & 0.85 \\
\hline 516 & Training for pastoral work, etc. & 0.41 \\
\hline 521 & Agricultural college & 0.91 \\
\hline 531 & Laboratory college & 0.77 \\
\hline 536 & Technical college & 0.77 \\
\hline 541 & Transport, communication and traffic college & 0.86 \\
\hline 551 & Nursing college, physiotherapy college & 0.29 \\
\hline 552 & College for medical laboratory science & 0.67 \\
\hline 554 & Dietetics college, etc. & 0.55 \\
\hline 561 & Business science college, exclusive of administrative and fiscal studies & 0.90 \\
\hline 562 & Courses for ergonomists and management science at the higher technical school, etc. & 0.84 \\
\hline 566 & Business science college, legal and administrative studies & 0.88 \\
\hline 571 & College of social studies, library studies & 0.64 \\
\hline 583 & Hotel college & 0.89 \\
\hline 586 & Art academy, academy of dramatic art & 0.78 \\
\hline 606 & Teacher training (highest level) & 0.26 \\
\hline 611 & Language and literature & 0.52 \\
\hline 616 & Theology & 0.49 \\
\hline 621 & Agricultural and domestic sciences & 0.82 \\
\hline 631 & Mathematics and physics & 0.82 \\
\hline 636 & Technical sciences & 0.68 \\
\hline 651 & Medical sciences & 0.22 \\
\hline 652 & Pharmacy & 0.50 \\
\hline 661 & Economics and business administration (B.A.) & 0.86 \\
\hline 662 & Econometrics, actuary and management (B.Sc.) & 0.80 \\
\hline 666 & Law & 0.70 \\
\hline 671 & Socio-cultural sciences & 0.66 \\
\hline 686 & Fine arts & 0.79 \\
\hline
\end{tabular}




\begin{tabular}{|c|c|c|}
\hline Code & Name & GH \\
\hline 301 & General secondary education & 0.94 \\
\hline 321 & Junior agricultural education & 0.58 \\
\hline 331 & Junior technical education & 0.93 \\
\hline 341 & Junior transport, communication and traffic education & 0.78 \\
\hline 351 & Junior medical and paramedical education & 0.63 \\
\hline 361 & $\begin{array}{l}\text { Lower business education, secondary school for tradesmen (lower level), practical } \\
\text { training for clerks and salesmen at the school for domestic science and technique }\end{array}$ & 0.91 \\
\hline 381 & School for domestic science and technique exclusive of training for clerks and salesmen & 0.89 \\
\hline 391 & Business security and surveillance training & 0.77 \\
\hline 401 & General secondary education, intermediate and higher levels & 0.94 \\
\hline 406 & Training for driving instructor, sports coach & 0.57 \\
\hline 421 & Senior agricultural education & 0.55 \\
\hline 431 & Senior school for laboratory science & 0.80 \\
\hline 436 & Senior technical training & 0.94 \\
\hline 441 & Senior education in transportation, communication and traffic science & 0.79 \\
\hline 451 & $\begin{array}{l}\text { Training of nurses and medical receptionists at the secondary school } \\
\text { for medical and other services }\end{array}$ & 0.41 \\
\hline 452 & Secondary school for medical laboratory science, higher level & 0.69 \\
\hline 453 & Training for medical clerks, etc. & 0.49 \\
\hline 454 & Training for ward orderlies, etc. & 0.45 \\
\hline 461 & Senior retail school and intermediate business education & 0.89 \\
\hline 466 & Intermediate business education, department of management studies & 0.36 \\
\hline 471 & Social work and welfare work (secondary school for medical and other services) & 0.80 \\
\hline 481 & $\begin{array}{l}\text { External care, services as taught at the secondary school for medical and other } \\
\text { services or the INTAS }\end{array}$ & 0.83 \\
\hline 483 & Secondary hotel and catering school, hairdresser's school & 0.46 \\
\hline 486 & Fashion drawing, etc. & 0.80 \\
\hline 506 & $\begin{array}{l}\text { Training college for primary and pre-primary school teachers, secondary-school } \\
\text { teacher training, new style }\end{array}$ & 0.34 \\
\hline 511 & Training for interpreters and translators & 0.80 \\
\hline 516 & Training for pastoral work, etc. & 0.38 \\
\hline 521 & Agricultural college & 0.87 \\
\hline 531 & Laboratory college & 0.90 \\
\hline 536 & Technical college & 0.94 \\
\hline 541 & Transport, communication and traffic college & 0.85 \\
\hline 551 & Nursing college, physiotherapy college & 0.33 \\
\hline 552 & College for medical laboratory science & 0.39 \\
\hline 554 & Dietetics college, etc. & 0.55 \\
\hline 561 & Business science college, exclusive of administrative and fiscal studies & 0.94 \\
\hline 562 & Courses for ergonomists and management science at the higher technical school, etc. & 0.81 \\
\hline 566 & Business science college, legal and administrative studies & 0.68 \\
\hline 571 & College of social studies, library studies & 0.75 \\
\hline 583 & Hotel college & 0.70 \\
\hline 586 & Art academy, academy of dramatic art & 0.74 \\
\hline 606 & Teacher training (highest level) & 0.26 \\
\hline 611 & Language and literature & 0.35 \\
\hline 616 & Theology & 0.48 \\
\hline 621 & Agricultural and domestic sciences & 0.78 \\
\hline 631 & Mathematics and physics & 0.66 \\
\hline 636 & Technical sciences & 0.88 \\
\hline 651 & Medical sciences & 0.26 \\
\hline 652 & Pharmacy & 0.65 \\
\hline 661 & Economics and business administration (B.A.) & 0.86 \\
\hline 662 & Econometrics, actuary and management (B.Sc.) & 0.80 \\
\hline 666 & Law & 0.73 \\
\hline 671 & Socio-cultural sciences & 0.67 \\
\hline 686 & Fine arts & 0.65 \\
\hline
\end{tabular}

